
of Engineers $S_{\circledast}$

Engineer Research and

Development Center

Water Operations Technical Support (WOTS) Program

\title{
Evaluation of Koontz Lake (North Indiana) Ecological Restoration Options - Comparison of Dredging and Aeration - and Broad Application to USACE Projects
}

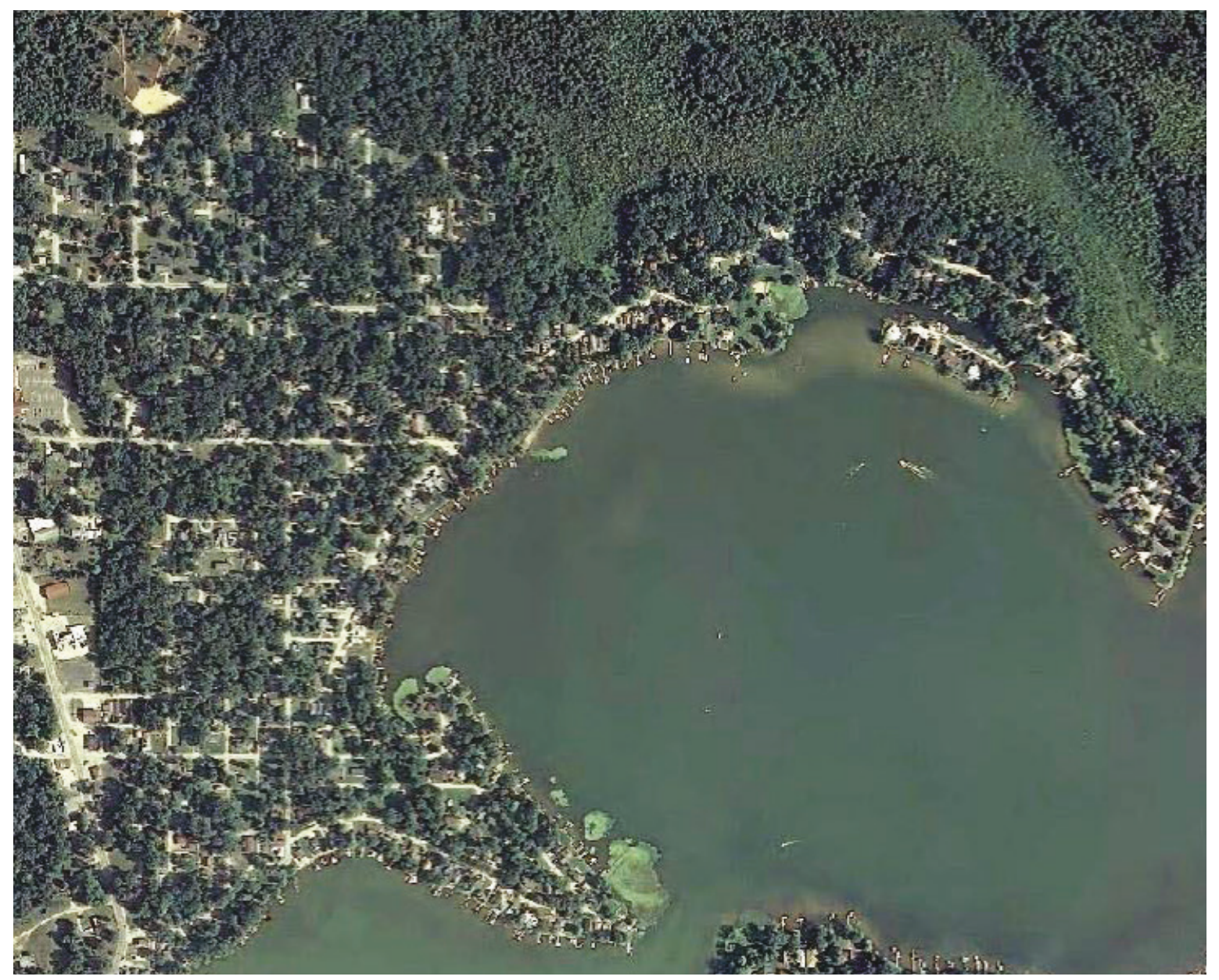


The U.S. Army Engineer Research and Development Center (ERDC) solves the nation's toughest engineering and environmental challenges. ERDC develops innovative solutions in civil and military engineering, geospatial sciences, water resources, and environmental sciences for the Army, the Department of Defense, civilian agencies, and our nation's public good. Find out more at www.erdc.usace.army.mil.

To search for other technical reports published by ERDC, visit the ERDC online library at http://acwc.sdp.sirsi.net/client/default. 


\section{Evaluation of Koontz Lake (North Indiana) Ecological Restoration Options - Comparison of Dredging and Aeration - and Broad Application to USACE Projects}

Victor F. Medina, Kaytee Pokrzywinski, and Edith Martinez-Guerra

Environmental Laboratory

U.S. Army Engineer Research and Development Center

3909 Halls Ferry Road

Vicksburg, MS 39180-6199

Final report

Approved for public release; distribution is unlimited.

Prepared for Water Operations Technical Support Program

3909 Halls Ferry Road

Vicksburg, MS 39180

Under Project No. TA2017-002, “Evaluation of Koontz Lake (Indiana) Environmental Restoration Options" 


\section{Abstract}

Koontz Lake is located in northern Indiana. The lake has had problems with eutrophication, harmful algae, invasive plants, and shallowing due to accumulation of sediment and muck. A study was conducted to assist in evaluating between two ecological restorative options under consideration: aeration and dredging. In this report, both approaches are defined, and various options of each are discussed. The impact of each approach is assessed for key water quality/ecological parameters. The specific needs of Koontz Lake are then discussed. In the case of Koontz Lake, the shallow portions of the lake appear to limit the effectiveness of aeration. Dredging would allow increased recreational use of the lake, particularly minimizing limitations on boating speeds. However, aeration could be integrated for long-term management of the lake. This report summarizes recommendations for Koontz Lake that have a greater applicability to other U.S. Army Corps of Engineers lake/reservoir projects. Several other alternatives are also presented, specifically the use of PhosLock, iron, and alum to bind phosphorus in sediments. (The U.S. Army Engineer Research and Development Center does not endorse any specific products or brands).

DISCLAIMER: The contents of this report are not to be used for advertising, publication, or promotional purposes. Citation of trade names does not constitute an official endorsement or approval of the use of such commercial products. All product names and trademarks cited are the property of their respective owners. The findings of this report are not to be construed as an official Department of the Army position unless so designated by other authorized documents. 


\section{Contents}
Abstract
Figures and Tables...
...v

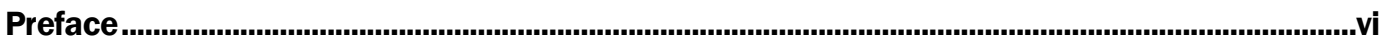
Unit Conversion Factors Table...............................................................................................................vii
Notation ............................................................................................................................................... vili

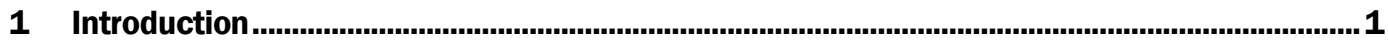

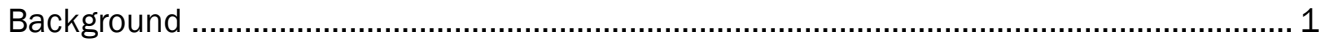

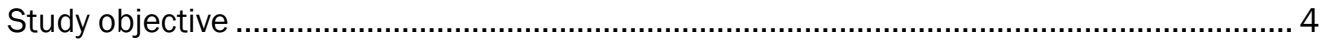

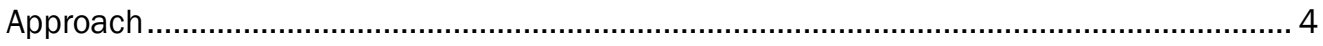

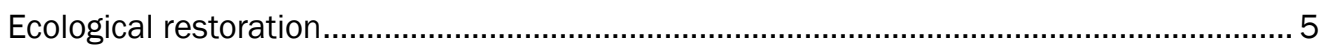

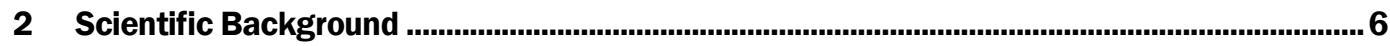

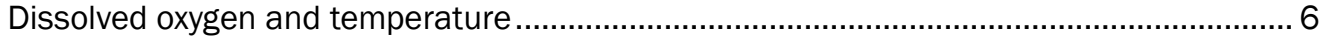

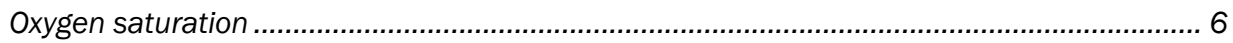

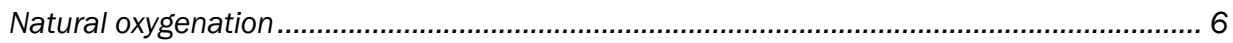

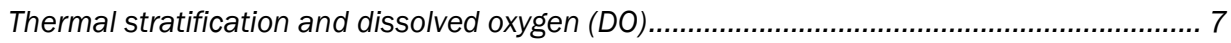

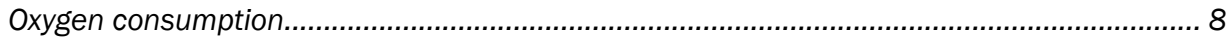

Organic matter and microbial organisms.................................................................. 8

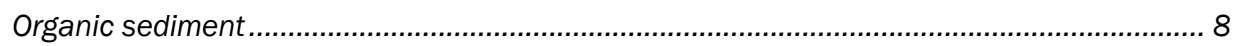

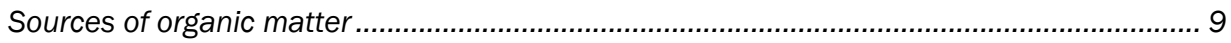

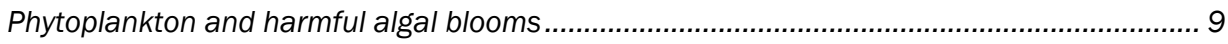

Aquatic plant species ......................................................................................... 10

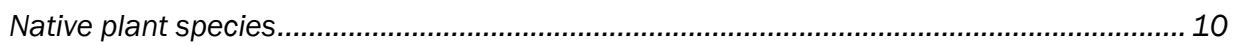

Invasive plant species.................................................................................................... 10

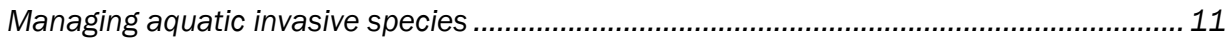

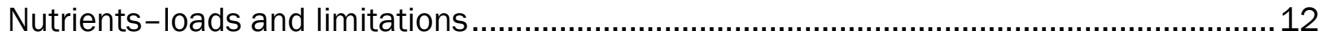

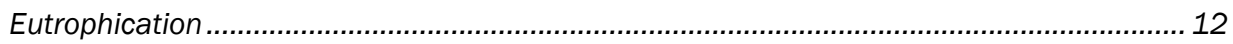

Phosphorus as a key limiting nutrient.............................................................................. 12

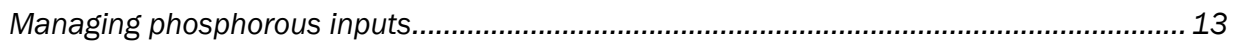

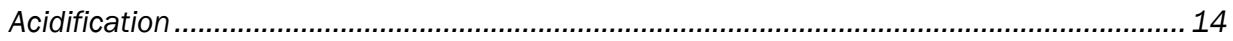

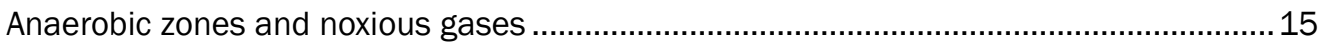

Turbidity and sedimentation ...................................................................................... 16

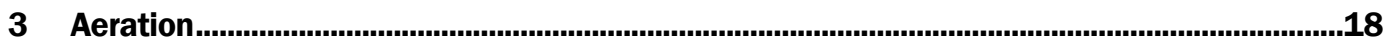

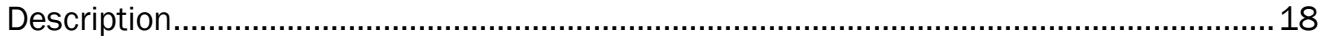

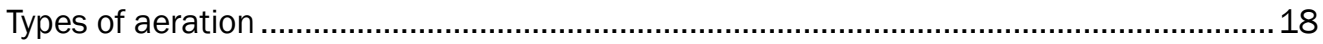

Examples of subsurface aeration.......................................................................... 19

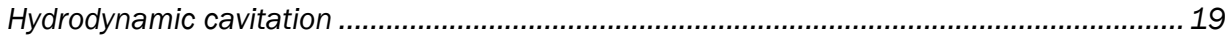

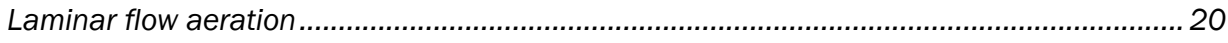

Examples of aeration for ecological restoration ........................................................20 


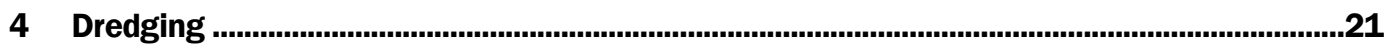

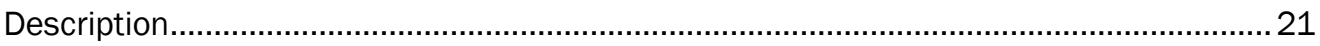

Types of dredging ..................................................................................................... 21

Examples of dredging for ecological restoration ........................................................ 22

5 Direct Comparison of Aeration and Dredging ..................................................................23

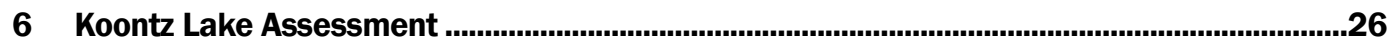

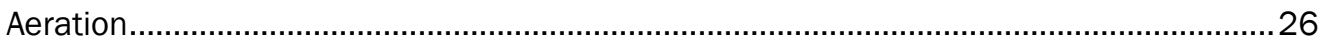

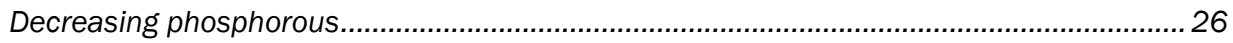

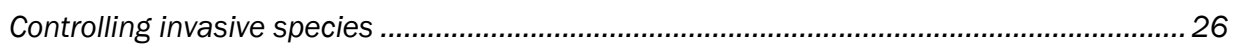

Reduction in sedimentation ................................................................................................ 26

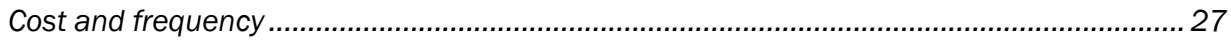

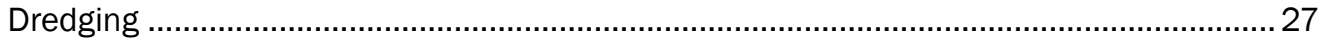

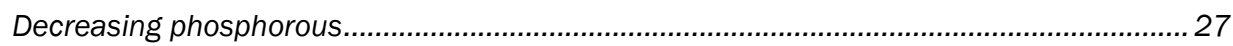

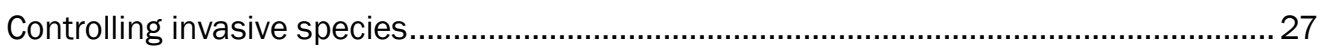

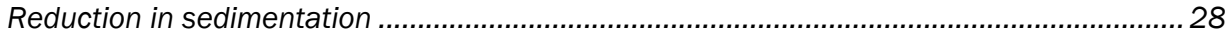

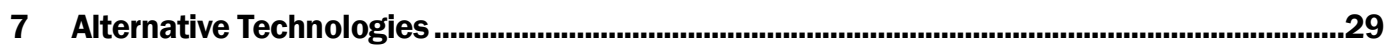

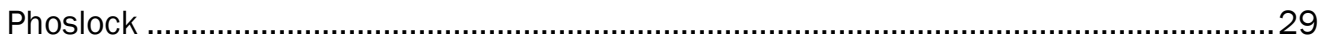

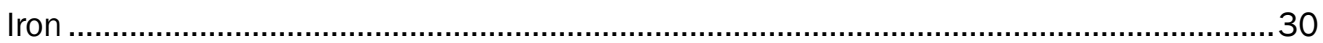

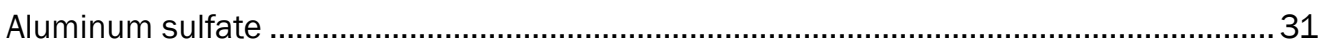

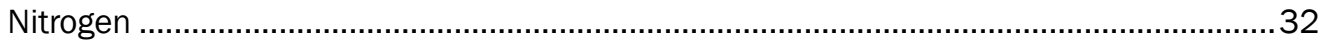

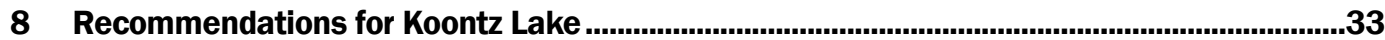

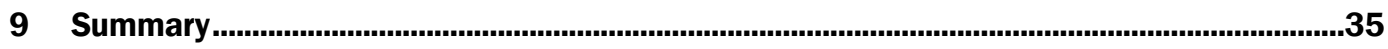

10 Conclusions...........................................................................................................................36

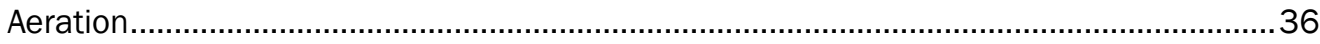

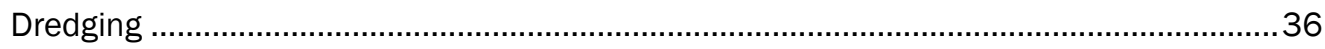

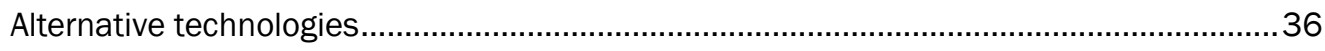

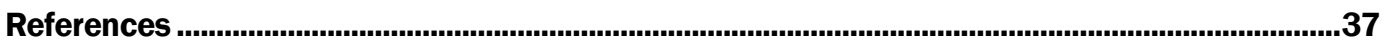

Report Documentation Page 


\section{Figures and Tables}

\section{Figures}

Figure 1. An aerial photograph of Koontz Lake.............................................................................

Figure 2. Oxygen saturation concentration in water at different temperatures. .................................. 6

Figure 3. Stratification in a lake, found typically in the summer. Solid line indicates temperature trend while dashed line represents $\mathrm{DO}$. The red region is considered the epilimnion, green thermocline/metalimnion, and blue the hypolimnion defined by the sharp temperature changes/differences between the regions.............................................................

Figure 4. Orthophosphate or reactive phosphate.........................................................................13

Figure 5. Phosphorus interactions with sediment, water, and organisms. ......................................14

Figure 6. Hypothetical example of a daily $\mathrm{pH}$ cycle during summer from Wurts (2003)....................15

Figure 7. Example of a LFA approach (adapted from a diagram prepared by Clean-Flo (https://www.clean-flo.com/inversion-oxygenation/))...............................................................................20

\section{Tables}

Table 1. Common mechanical and chemical management options for controlling aquatic

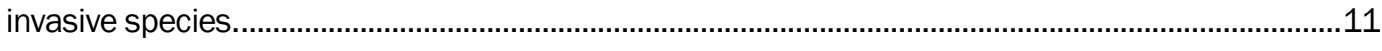

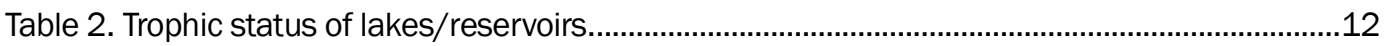

Table 3. A comparison of methods by environmental factor. ............................................................23

Table 4. Summary of impacts on environmental factors....................................................................35 


\section{Preface}

The work reported herein was conducted at the U.S. Army Engineer Research and Development Center (ERDC), Environmental Laboratory (EL), Vicksburg, MS, under the project "Evaluation of Koontz Lake (Indiana) Environmental Restoration Options.” The project was funded by the Water Operations Technical Support (WOTS) Program, managed by Dr. Pat Deliman.

Peer review of this report was provided by Dr. Catherine Thomas and by Mr. Kurt Getsinger.

At the time of publication of this report, Dr. W. Andy Martin was Chief of the Environmental Engineering Branch; Mr. Warren P. Lorentz was Chief of the Environmental Processes and Engineering Division; Dr. Pat Deliman was the Director of EL.

COL Bryan S. Green was Commander of ERDC, and Dr. David W. Pittman was ERDC Director. 


\section{Unit Conversion Factors Table}

\begin{tabular}{|l|c|l|}
\hline Multiply & By & To Obtain \\
\hline acres & $4,046.873$ & square meters \\
\hline acre-feet & $1,233.5$ & cubic meters \\
\hline cubic feet & 0.02831685 & cubic meters \\
\hline degrees Fahrenheit & $($ F-32)/1.8 & degrees Celsius \\
\hline feet & 0.3048 & meters \\
\hline gallons (U.S. liquid) & 3.785412 E-03 & cubic meters \\
\hline inches & 0.0254 & meters \\
\hline
\end{tabular}




\section{Notation}

$\begin{array}{ll}\text { CyanoHAB } & \text { Cyanobacterial and Harmful Algal Blooms } \\ \text { DO } & \text { dissolved oxygen } \\ \text { EL } & \text { Environmental Laboratory } \\ \text { ERDC } & \text { U.S. Army Engineer Research and Development } \\ & \text { Center } \\ \mathrm{ft} & \text { foot, feet } \\ \mathrm{g}, \mathrm{kg}, \mathrm{mg}, \mu \mathrm{g}, \mathrm{ng} & \text { gram, kilogram, milligram, microgram, nanogram } \\ \text { gal } & \text { gallon } \\ \text { in. } & \text { inch } \\ \text { L, mL } & \text { liter, milliliter } \\ \text { LPD } & \text { Lawrence Pontius Ditch } \\ \text { m, mm, cm } & \text { meter, millimeter, centimeter } \\ \text { U.S. } & \text { United States } \\ \text { USACE } & \text { United States Army Corps of Engineers } \\ \text { WOTS } & \text { Water Operations Technical Support Program } \\ \text { WRDA } & \text { Water Resources Development Act }\end{array}$




\section{Introduction}

\section{Background}

Koontz Lake (Figure 1) is a freshwater lake in northern Indiana that drains over 4,100 acres in Marshall and Starke counties (JFNew 2010). The lake is publically owned and is 346 acres in size, receiving water from springs and ditches (Lawrence Pontius and Schoeder Ditches) as well as from surface runoff. Koontz Lake has a mean depth of 12 feet $(\mathrm{ft})(3.7 \mathrm{~m})$ (maximum $30 \mathrm{ft}[9.1 \mathrm{~m}]$ ) and drains into Robbins Ditch on its western side of the reservoir.

Figure 1. An aerial photograph of Koontz Lake.

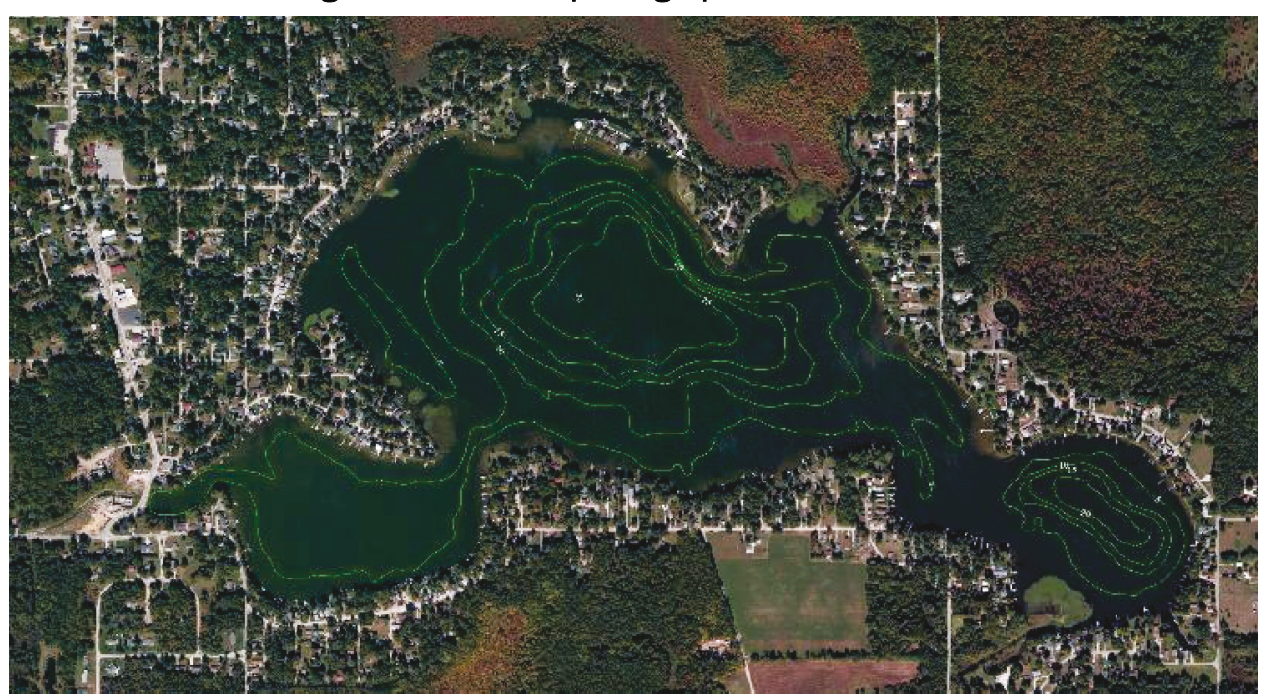

Historically, there was no inlet in Koontz Lake until the 1930s when the Lawrence Pontius Ditch (LPD) was constructed to provide irrigation access to the lake. After construction of the LPD, water, sediment, and nutrients from the 6.5 square mile $\left(16.8 \mathrm{~km}^{2}\right)$ basin were available for deposition into the lake via surface runoff. Prior to 1955, it is unclear how much sediment and nutrients were deposited in Koontz Lake from external sources. However, between 1955 (first bathymetry) and 1988, the volume of the lake was reduced by $21 \%$ owing to increased sedimentation from the larger drainage area. Furthermore, in the 1990 s a sediment trap and wetland were constructed adjacent to Koontz Lake to reduce sediment and nutrient loads. This improved the sedimentation problem but has not eliminated it. 
Consequently, the increased drainage area to Koontz Lake has caused an increase in sediment deposition and nutrient loads that are nearing eutrophic levels. Soft sediment, or muck, has accumulated on the lake bottom and can be suspended by boat propellers (Tacy and Matus 2001); this can lower water clarity and allow for enhanced desorption of nutrients in the suspended material. Once suspended, the sediment particles can take weeks or months to settle.

Phosphorus is also an issue. Lake Koontz has had a slow but steady increase in total phosphorus, and its average has been reported at 77 micrograms per liter $(\mu \mathrm{g} / \mathrm{L})$, and spikes have been two to three times higher (JFNew 2010). The eutrophic levels for total phosphorous are above $84 \mu \mathrm{g} / \mathrm{L}$ (Table 1), indicating that these waters are approaching an average that is within the eutrophic classification range. Furthermore, the source of phosphorous may be shifting. A report from 2009 noted slightly higher concentrations of soluble reactive phosphorous (SRP) ( $\sim 1.5$ fold higher) in the hypolimnion than the epilimnion between 1993 and 2004, suggesting internal loading from sediment release (JFNew 2010). However, in 2009 the concentration of SRP was 6.7 times higher in the hypolimnion than in the epilimnion. This can likely be attributed to sedimentation of particulates and algae instead of desorption of phosphorous from the sediment (JFNew 2010). The U.S. Army Corps of Engineers (USACE) (Detroit District), in compliance with Sec 206, Water Resources Development Act (WRDA) 1996, previously recommended dredging to deepen the lake and reduce nutrient re-suspension. However, the Koontz Lake Association is very interested in exploring other management approaches.

In coincidence with increased nutrient loading and sedimentation, there has been an increase in the occurrence of aquatic invasive species. In October 2016, Koontz Lake contained approximately 50 acres of the submerged hybrid aquatic invasive species Eurasian watermilfoil (Myriophyllum sibiricum X Myriophyllum spicatum), and this increased to approximately 82 acres in spring 2008 (JFNew 2010). The timing of each study likely impacted the abundance of this species as one was conducted in the spring and one in the fall; however, it is obvious that Eurasian watermilfoil is a persistent problem in Koontz Lake. Furthermore, due to the high water clarity of Koontz Lake, Eurasian watermilfoil growth is capable at nearly all depths of the littoral zone where light is not limited ( 9 ft [2.7 m] deep) (Jermalowicz-Jones 2017). 
Additionally, Eurasian watermilfoil has a faster growth rate than other plants and may effectively displace other native vegetation (Les and Philbrick 1993; Vilá et al. 2000). Koontz Lake contains two other invasive plant species: curly-leaf pondweed, which is also submersed, and purple loosestrife, an emergent aquatic plant. In the 2016 study, (JermalowiczJones 2017) curly-leaf pondweed was found in only two locations in the littoral zone at the lake perimeter, where in the 2009 study (JFNew 2010) it covered approximately 42 acres 17 hectares), about $12 \%$ of the lake's surface. The 2009 study was conducted in May where the 2017 study was conducted in October, which could explain the difference in density of curly-leaf pondweed. Additionally, the decline in curly-leaf pondweed may be due to management tactics applied early in the season owing to timing differences of the studies. Considering that Koontz Lake has an infestation of Eurasian watermilfoil that covers approximately $14 \%$ of the lake, the control and spread of this and other invasive species should be taken into consideration when identifying ecological restoration options. For example, Eurasian watermilfoil can spread through plant fragmentation where curly-leaf pondweed is spread through turions (Jermalowicz-Jones 2017). Methods that physically agitate the plant may not be ideal for treating Eurasian watermilfoil but may be ideal for curly-leaf pondweed. In general, the overall goal is to selectively control invasive plants to stimulate the growth of native vegetation.

Much like invasive plants, native plants can grow to nuisance levels in the presence of excess nutrients and low turbidity. The diversity of aquatic plants is essential to the stability of aquatic ecosystems because each harbors unique macro-invertebrate and microbial communities and provides differing habitats for fish. Koontz Lake has 11 native submersed aquatic plants, dominated by Chara and thin-leaf pondweed (Potamogeton pectinatus) (Jermalowicz-Jones 2017). Overall, Koontz Lake has 22 native aquatic plant species (including emergent and floating plants) making for a diverse aquatic ecosystem; therefore, the control of invasive species and the associated nutrient loading are essential to maintain the ecological health and biodiversity of Koontz Lake.

Increased nutrient loading also contributes to the formation and persistence of cyanobacteria harmful algal blooms (CyanoHABs) in freshwater systems. Cyanobacteria are typically associated with degraded water quality in that they form dense blooms, cause taste and odor issues, provide poor food quality for higher trophic levels, and excrete harmful 
toxins; collectively this makes cyanobacteria a concern for ecosystem health. Historically, Koontz Lake has had several issues with cyanobacteria. The 2008 study (JFNew 2010) showed that cyanobacteria was the most abundant genera found and accounted for over half of total phytoplankton density. Within the cyanobacteria, Anabaena sp. accounted for $99.7 \%$ of the diversity; however, no bloom was present during sampling. Other sampling trips did however reveal CyanoHABs events dominated by filamentous algae in the spring (65\%) and summer (74\%) (JFNew 2009). In the fall of 2016, generally speaking, there was a much more diverse group of phytoplankton comprised of a mixture of green algae, cyanobacteria, and diatoms representing a more balanced microbial community (Jermalowicz-Jones 2017). Again the difference in cyanobacteria abundance and algal biodiversity is linked to the time of year that sampling occurred in each study. In the fall the water column is typically more mixed, and there is decreased light providing less opportunity for cyanobacteria to bloom, where in the spring, winter runoff provides excessive nutrients, light is available, and thermal stratification sets in, providing conditions that stimulate algal growth.

\section{Study objective}

This project consisted of a review of two ecological restoration options for Koontz Lake (see below), aeration/mixing and dredging, to assess effectiveness regarding the following:

- control of increasing levels of phosphorus in the water column

- control of invasive plants, particularly Eurasian watermilfoil (Myriophyllum spicatum) that are found in the shallow areas of the lake

- control of increasing sediment/muck thicknesses in the shallow portions of the lake.

There will also be an exploration of several other alternatives and a discussion of these methods from a broader USACE context.

\section{Approach}

This study focused on a review of documents about Koontz Lake as well as on a review of literature, discussions with experts in the field, and professional experience and judgment. 


\section{Ecological restoration}

Ecological restoration refers to actions taken to improve or restore ecosystems, habitats, and natural environments that have been damaged or degraded by human activity. In the case of lakes and reservoirs, these activities can include the following:

- addressing restoration of water quality, including removal of contaminants, reduction of suspended sediment or turbidity, adjustment of aquatic $\mathrm{pH}$, adjustment of temperature (usually lowering), and increasing dissolved oxygen (DO)

- addressing sediment filling, which may include traps to reduce sediment loading in the lake/reservoir or dredging

- addressing invasive plant species, which may include removal of these species or changes in the environment that favor the growth of desirable native species

- addressing degradation of fish habitat, which may include changes in water quality, restoration of breeding habitat, and removal of invasive fish species

- addressing habitat of riparian species, like birds and other species that may live on the near shore environments (Medina et al. 2016a). 


\section{Scientific Background}

\section{Dissolved oxygen and temperature}

\section{Oxygen saturation}

Oxygen is a critical aspect of ecological health of lake systems.

Multicellular organisms cannot survive without oxygen. Low oxygen levels can inhibit high-end predator species, such as trout and bass. These organisms are valued for sporting and economic purposes. Many invasive species take advantage of low oxygen conditions to displace native species.

Oxygen makes up approximately $21 \%$ of atmospheric air. However, the oxygen-carrying capacity of water is far less than air and is strongly dependent on temperature (Figure 2). At $\mathrm{O}^{\circ} \mathrm{C}$, the saturated dissolved oxygen (DO) concentration is approximately 14.2 milligrams per liter (mg/L), and this decreases as temperature increases. Furthermore, aquatic systems are typically not at saturated conditions, and the DO levels are usually lower.

Figure 2. Oxygen saturation concentration in water at different temperatures.

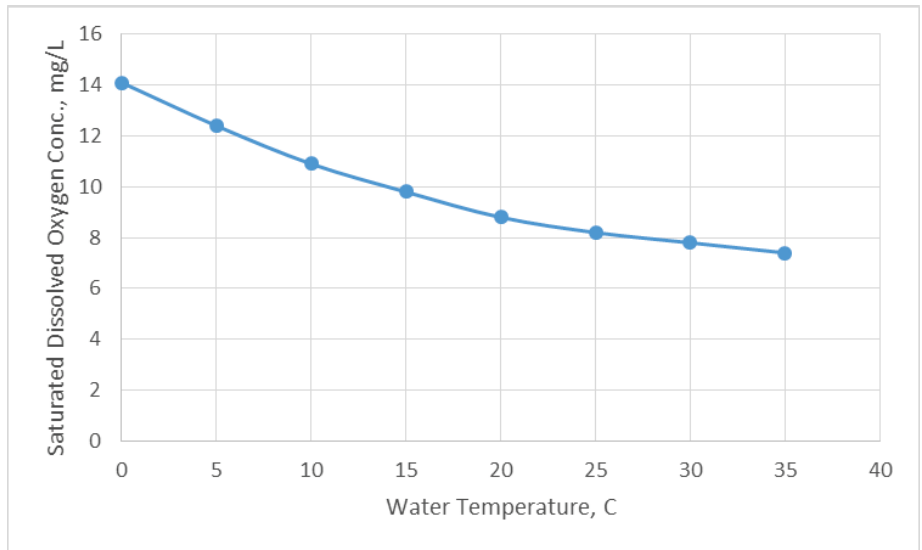

\section{Natural oxygenation}

There are four primary mechanisms for oxygenation of water bodies. First, there is diffusion of air from the atmosphere at the water surface. This process is nearly continuous because, as mentioned above, natural water is rarely saturated. Diffusion can be slow but is often the only means of reoxygenation. Second, air can be turbulently mixed with water via shear stress from wind. Wind turbulence can greatly increase the aeration rate 
but usually occurs over relatively short periods. Third, aeration can occur from stream/riverine inputs into the lake. Typically, streams have higher oxygen concentrations because they are generally cooler (having a higher oxygen saturation) and have air entrained due to the water movement itself. Finally, aeration can occur from photosynthetic reactions from plants, algae, and cyanobacteria.

\section{Thermal stratification and dissolved oxygen (DO)}

Lake stratification refers to a condition in which a physical gradient, such as temperature, serves to limit or restrict mixing in the lake. Stratification commonly occurs in summer when solar heating at the surface creates a high temperature region called the epilimnion (Figure 3). Cooler, denser water is found with depth in the hypolimnion. These are separated by a sharp temperature gradient called the thermocline. Differences in temperature and density above and below the thermocline limit mixing between these regions. Stratification is most extreme in the summer.

During spring and fall, lakes typically overturn, resulting in mixing of the lower and upper layers. Koontz Lake, like most lakes in the U.S. Midwest, undergoes this stratification pattern.

Figure 3. Stratification in a lake, found typically in the summer. Solid line indicates temperature trend while dashed line represents DO. The red region is considered the epilimnion, green thermocline/metalimnion, and blue the hypolimnion defined by the sharp temperature changes/differences between the regions.

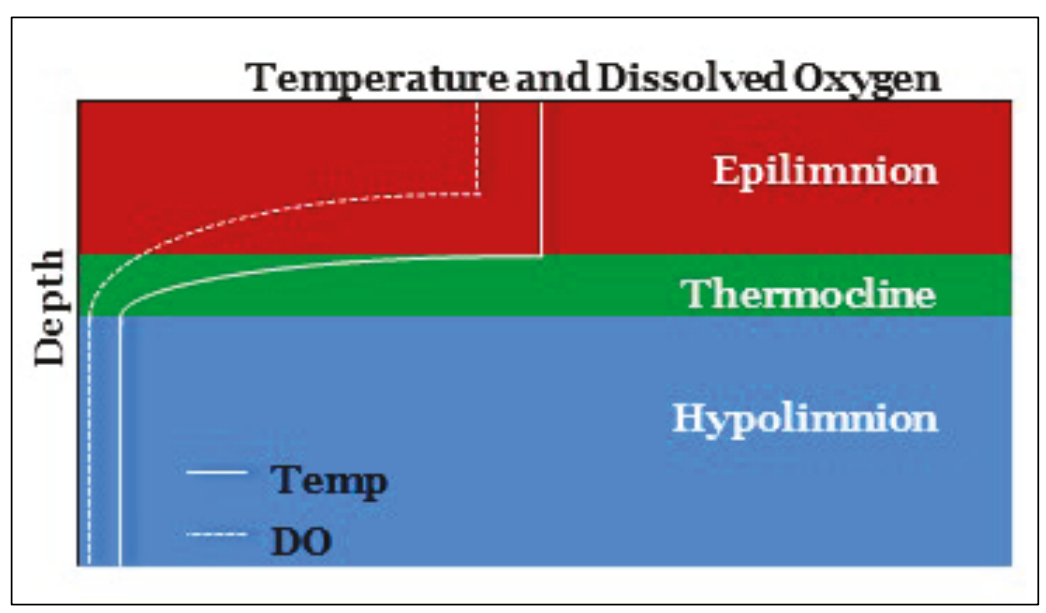

DO levels are closely linked to thermal stratification where the persistence of a thermocline inhibits the atmospheric diffusion of oxygen into the hypolimnion (Figure 3). Furthermore, light-harvesting autotrophs such as phytoplankton release oxygen at or above the thermocline where sunlight 
is readily available, contributing to a greater oxygen pool in surface waters. That being said, the hypolimnion is often too deep to support photosynthetic organisms that produce oxygen. Thus, waters below the thermocline typically receive very little inputs of oxygen during times of stratification. Therefore, natural aeration in lakes tends to be largely at or near the surface (via diffusion, turbulence/mixing, and photosynthetic inputs as mentioned above). Consequently, the near surface tends to have the highest oxygen concentrations (Figure 3). Wind and current mixing can keep oxygen levels relatively high for depth of 1 meter (m) or so, but at increasing depth oxygen diffusion can become more limited, particularly if the lake is highly stratified. Therefore, oxygen depletion tends to be most severe with depth.

\section{Oxygen consumption}

Oxygen in lakes is largely consumed by organisms living in the water. These include microorganisms of all kinds, fish and other aquatic animals, plants, and algae (which also respire). Oxygen is consumed during aerobic respiration in which organic matter is consumed by organisms to generate energy for movement and metabolic processes.

$$
\mathrm{C}_{6} \mathrm{H}_{12} \mathrm{O}_{6}(\text { glucose / organic matter })+6 \mathrm{O}_{2}=6 \mathrm{H}_{2} \mathrm{O}+6 \mathrm{CO}_{2}+\text { Energy }
$$

Since organic matter is needed for respiration, it can become a limiting factor in oxygen consumption that leads to hypoxic and anoxic systems. For example, lakes with low organic matter have oxygen throughout most of the water column. However, lakes with high organic matter content can have respiration rates that can consume enough DO to create hypoxic and anoxic zones throughout the lake. Low DO levels can adversely affect fish survivability and health (Doudoroff and Shumway 1970).

\section{Organic matter and microbial organisms}

\section{Organic sediment}

Large buildups of organic sediment or muck are common to many freshwater lakes/reservoirs. This is the result of years of nutrient and organic matter loading into the water. When oxygen is available, beneficial microbes and insects decompose the organic sediment, which reduces the accumulation of muck, resulting in lower turbidity and dissolved nutrients in the lake. However, when oxygen is depleted, anaerobic bacteria only partially break down the organic material and in the process release 
noxious gases (discussed in more detail below). This causes an increase in sediment thickness and consequences associated with the released gases like hydrogen sulfide, resulting in the dilapidation of aquatic ecosystems.

\section{Sources of organic matter}

Organic matter is anything that contains carbon compounds from a living organism. A commonly known form of organic matter is from the bacterial degradation of organisms (both plants and animals). Additionally, organic matter is produced from the natural excrement of metabolic waste products; these can either be released in the lake or enter the lake via surface runoff. Organic matter can also come from external sources, like vegetation that falls into the lake (particularly in autumn, when leaf litter can be blown into the lake) or carried into the lake from influent streams or through surface runoff. Anthropogenic inputs can also greatly affect organic matter, particularly by discharges of stormwater, sewage, industrial wastewater, and surface runoff. Some common contaminants in surface runoff include fertilizers, yard waste, and animal waste. However, the most important source of organic matter for most lakes and reservoirs is generated by the growth and subsequent decay of algae and cyanobacteria.

\section{Phytoplankton and harmful algal blooms}

Phytoplankton are an essential component to healthy ecosystems as they form the base of the food chain. They are important in biogeochemical cycling and buffer aquatic $\mathrm{pH}$ levels (photosynthetic reactions tends to make the environment more basic compared to respiration, which tends to produce acids). However, high photosynthetic primary productivity can result in severe negative consequences to ecosystem health. Dense plant and algal growth ultimately leads to severe oxygen depletion and the development of hypoxic/anoxic and/or anaerobic zones in the lake resulting in ecosystem degradation. CyanoHABs produce compounds that are toxic and that contribute to taste and odor problems. Compounds impacting taste and odor are generally not harmful to humans or ecosystem health but can result in a degradation of the aesthetic quality of the lake. However, cyanobacteria toxins are harmful to vertebrates (including humans) and therefore greatly degrade water quality. Additionally, Taranu et al. (2015) have demonstrated that CyanoHAB events have been steadily increasing in numbers and severity since 1950, making this a growing need to understand ecologically. The increase in harmful algae poses a threat to the ecological 
health of aquatic environments and directly impacts recreational use of lakes and reservoirs.

\section{Aquatic plant species}

\section{Native plant species}

Aquatic plants contribute to maintaining key functions and related biodiversity in freshwater ecosystems (Thomaz and da Cunha 2010). Aquatic macrophyte species are plants that have adapted to living in, on, or near aquatic systems. Macrophytes are extremely important to healthy lake environments. Native, multispecies macrophyte beds provide a food source, habitat, and breeding grounds that support biodiversity within the ecosystem. Macrophytes also reduce turbidity by holding in lake sediments, removing excess nutrients, and reducing the abundance of phytoplankton (reviewed in Hussner et al. 2017). The dominant aquatic plants in Koontz Lake include muskgrass (Chara vulgaris), thin leaf pondweed-more commonly called sago pondweed (Potamogeton pectinatus) -white-waterlily (Nymphaea odorata), yellow-waterlily (Nuphar variegate), duckweed (Lemna minor), giant duckweed (Spirodella sp.), cattails (Typha sp.) and bulrushes (Schoeneoplectus sp.) (Jermalowicz-Jones 2017). Realistically, some of the benefits provided by native macrophytes could also be provided by invasive macrophytes; however, this is dependent on the state of the system prior to infestation, the level of infestation, and the origin of the species.

\section{Invasive plant species}

As defined by the Nonindigenous Aquatic Nuisance Prevention and Control Act of 1990, aquatic invasive species are nonindigenous species that threaten the diversity and/or abundance of native species, the ecological stability of infested waters, and/or any commercial, agricultural, aquacultural, or recreational activities dependent on such waters. According to the Midwest Invasive Plant Network, several common invasive species in Indiana include hydrilla, Eurasian watermilfoil, and curly-leaf pondweed (http://www.mipn.org/plantlist/). Invasive species often look similar to native flora and therefore can be difficult to detect until a significant invasion has occurred. For example, Eurasian watermilfoil is often confused with the Indiana native plant northern watermilfoil. Although all macrophytes spread via propagules and by vegetative means, due to the invasive nature of nuisance/non-native species they are able to outcompete native flora. The dissemination of macrophytes is typically via transport on bird feathers, the fur of aquatic animals, boats, trailers, anchors, and in ballast water, making 
invasive species incredibly difficult to control and monitor. Additionally, aquatic invasive plant species have the potential to grow to such density that habitat value and recreational access are impeded. For example, infestations can form a physical barrier of dense vegetation that effectively prevents access to the substrates for nesting. This can result in a physical reduction in area available for spawning and consequent decline in the number of nests. Furthermore, the presence of dense mats of vegetation directly shades other native macrophytes and benthic organisms. Generally speaking, once a species has invaded a water body, management strategies are much more limited, and the consequences to water quality, wildlife, and human activity are severe.

\section{Managing aquatic invasive species}

There are three types of management options, including physical, chemical, and biological control methods. Each option varies greatly in its scale of application, cost, and effectiveness. Additionally, each option has its own advantages and disadvantages on both the target and non-target species and on the overall habitat. Some common control methods can be seen in Table 1. For a more detailed assessment of each method, see Hussner et al. (2017) and Gettys et al. (2014). However, in general, preventing the invasion and/or spread of aquatic invasive species appears to be the best from an ecological perspective. Still, early detection and rapid response is much easier said than done. To be successful, it requires major commitment of trained personnel on an annual basis, in combination with a management plan that is effective. Therefore, there are obvious ecological and economical trade-offs to consider when developing best management practices.

Table 1. Common mechanical and chemical management options for controlling aquatic invasive species.

\begin{tabular}{|l|l|}
\hline Mechanical & Chemical \\
\hline Mechanical harvesting/excavation & Triclopyr \\
\hline Pulverizing/shredding & Diquat \\
\hline Hand weeding & $2,4-D$ \\
\hline Suction dredging & Imazamox \\
\hline Benthic barriers & Imazapyr \\
\hline Water-level drawdown & Endothall \\
\hline Nutrient reduction & Fluridone \\
\hline
\end{tabular}




\section{Nutrients-loads and limitations}

\section{Eutrophication}

Eutrophication is the excessive enrichment of nutrients in lakes/reservoirs either through natural or anthropogenic means that leads to enhanced biological activity and decreased lake volume (Cooke et al. 1978; Cooke et al. 1993). Typically, eutrophication refers to increased nitrogen and/or phosphorous loading as these are essential macronutrients for photosynthetic primary production. Eutrophication typically leads to dense plant and algal growth that ultimately lead to severe oxygen depletion and the development of anoxic and/or anaerobic zones in the lake resulting in ecosystem degradation. The trophic status of lakes/reservoirs is presented in Table 2.

Table 2. Trophic status of lakes/reservoirs.

\begin{tabular}{|l|c|c|c|}
\hline Parameter & \multicolumn{1}{c}{ Oligotrophic } & Mesotrophic & Eutrophic \\
\hline Total phosphorous $(\mu \mathrm{g} / \mathrm{L})$ & 8 & 27 & 84 \\
\hline Total nitrogen $(\mathrm{mg} / \mathrm{L})$ & 0.661 & 0.753 & 1.875 \\
\hline Chlorophyll a $(\mu \mathrm{g} / \mathrm{L})$ & 1.7 & 4.7 & 14.3 \\
\hline
\end{tabular}

*Re-created from JFNew (2010) and Vollenweider (1975).

\section{Phosphorus as a key limiting nutrient}

Phosphorus is a particularly important nutrient because it is needed in relatively small concentrations compared to other nutrients in algal and plant growth. A small increase in phosphorus can cause undesirable effects on ecosystems. Total phosphorus levels of $84 \mu \mathrm{g} / \mathrm{L}$ in water can lead to eutrophic levels (Vollenweider 1975). Orthophosphate (Figure 4), which is often referred to as reactive phosphorus or simply phosphate, is highly available to plants and organisms and has an even more stringent level of $5 \mu \mathrm{g} / \mathrm{L}$ as a threshold to limit eutrophic conditions. 
Figure 4. Orthophosphate or reactive phosphate.

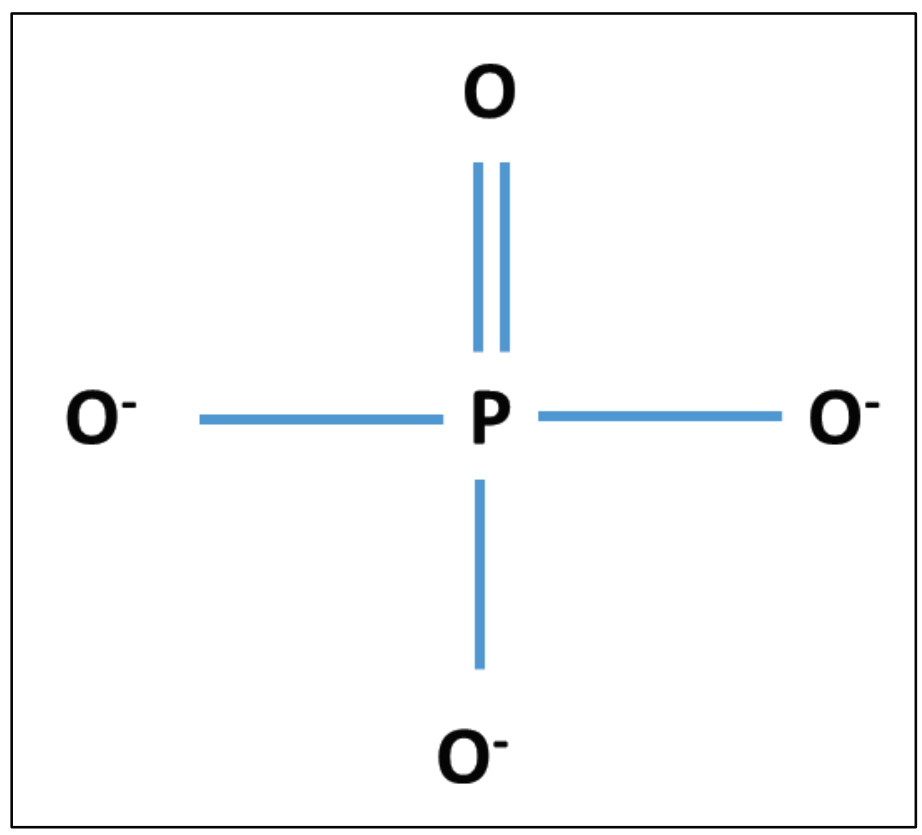

\section{Managing phosphorous inputs}

Although problematic, phosphorous is also considered the easiest nutrient to control in most aquatic settings. Controlling inputs of phosphorus is critical. Key sources of phosphorus include agricultural fertilizers, sewage waste, and some industrial wastes. Detergents may also contain phosphorus, but the concentrations in detergents have been greatly decreased due to regulation. Control can include source controls-limiting uses and discharges of phosphorus-containing materials. Control can also include engineered systems, like sediment traps to capture fertilizercontaining sediment before it enters a lake or the use of riparian strips or wetlands in which vegetation can uptake and remove nutrients.

Controlling inputs should be the first priority of any lacustrine ecosystem management program, but eliminating all inputs can be very difficult. Many nutrient control approaches focus on changing sediment/water interactions that affect nutrient availability. Phosphorus forms relatively stable, insoluble mineral species, which are biologically inert in sediments. If optimal conditions can be maintained, the sediment can bind relatively large quantities of phosphorus (Figure 5). With time as more sediment accumulates, the phosphorus can essentially be buried. Since phosphorous has no gaseous forms (unlike nitrogen, which can be a gas in the form of dissolved ammonia [Bartsch 1972]) the burial of bound phosphorous can essentially remove the nutrient from the system, at least until a physical disturbance re-suspends the material. 
Figure 5. Phosphorus interactions with sediment, water, and organisms.

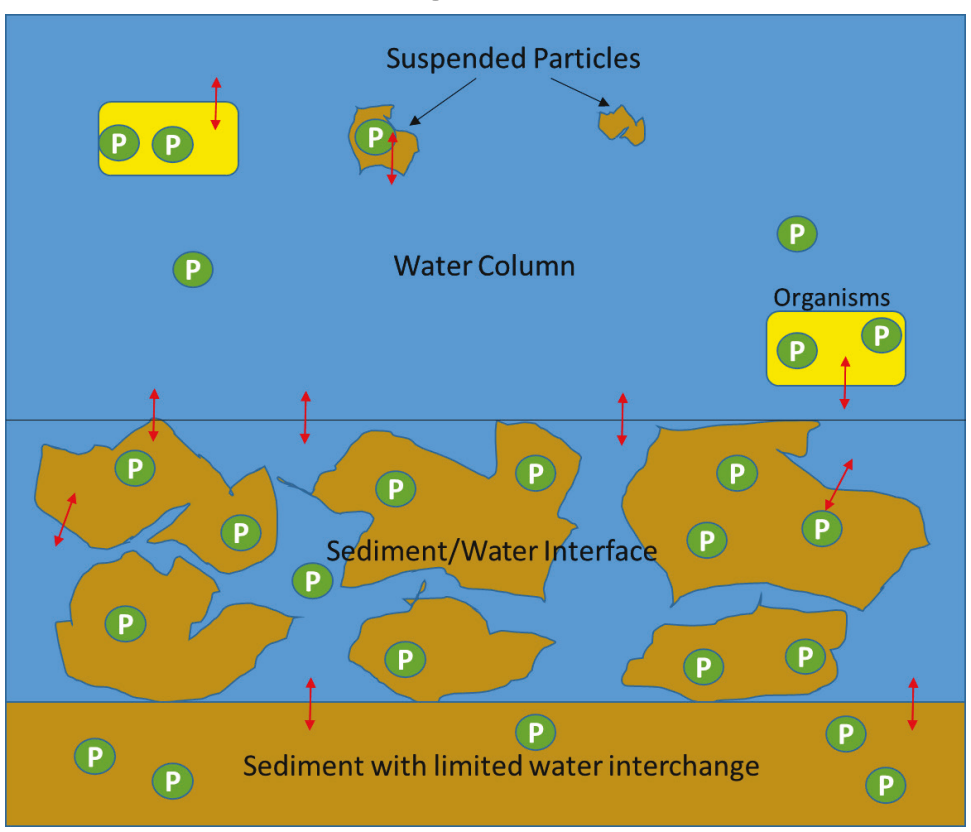

\section{Acidification}

Respiration, photosynthesis, and decomposition contribute to fluctuations in lake water $\mathrm{pH}$ owing to their associations with carbon dioxide $\left(\mathrm{CO}_{2}\right)$ consumption or production. $\mathrm{CO}_{2}$, like oxygen, can exist in a dissolved state in water but can also react with water to form carbonic acid $\left(\mathrm{H}_{2} \mathrm{CO}_{3}\right)$ (Equation 2). Carbonic acid can lose one or both of its hydrogen $\left(\mathrm{H}^{+}\right)$ions and contribute to a decrease in water $\mathrm{pH}$. This system can work in either direction, so if $\mathrm{CO}_{2}$ levels are low, then carbonic acid can react with $\mathrm{H}^{+}$ ions to form $\mathrm{CO}_{2}$ and water and increase $\mathrm{pH}$. This is referred to as bicarbonate buffering system (Wurts 2003).

$$
\mathrm{CO}_{2}+\mathrm{H}_{2} \mathrm{O} \Leftrightarrow \mathrm{H}_{2} \mathrm{CO}_{3} \Leftrightarrow \mathrm{CO}_{3}^{2+}+2 \mathrm{H}^{+}
$$

Aerobic respiration typically lowers the $\mathrm{pH}$ in aquatic systems because the energy is used to create organic acids. Photosynthesis is the opposite of respiration (reverse of Equation 1), using energy in the form of light and increasing $\mathrm{pH}$. Therefore, the two processes tend to balance each other, except during high periods of productivity. For example, as sunlight intensifies throughout the day, so does the rate of photosynthesis and therefore uptake of $\mathrm{CO}_{2}$, thus causing an increase of the $\mathrm{pH}$ in aquatic systems (Figure 6). 
Figure 6. Hypothetical example of a daily pH cycle during summer from Wurts (2003).

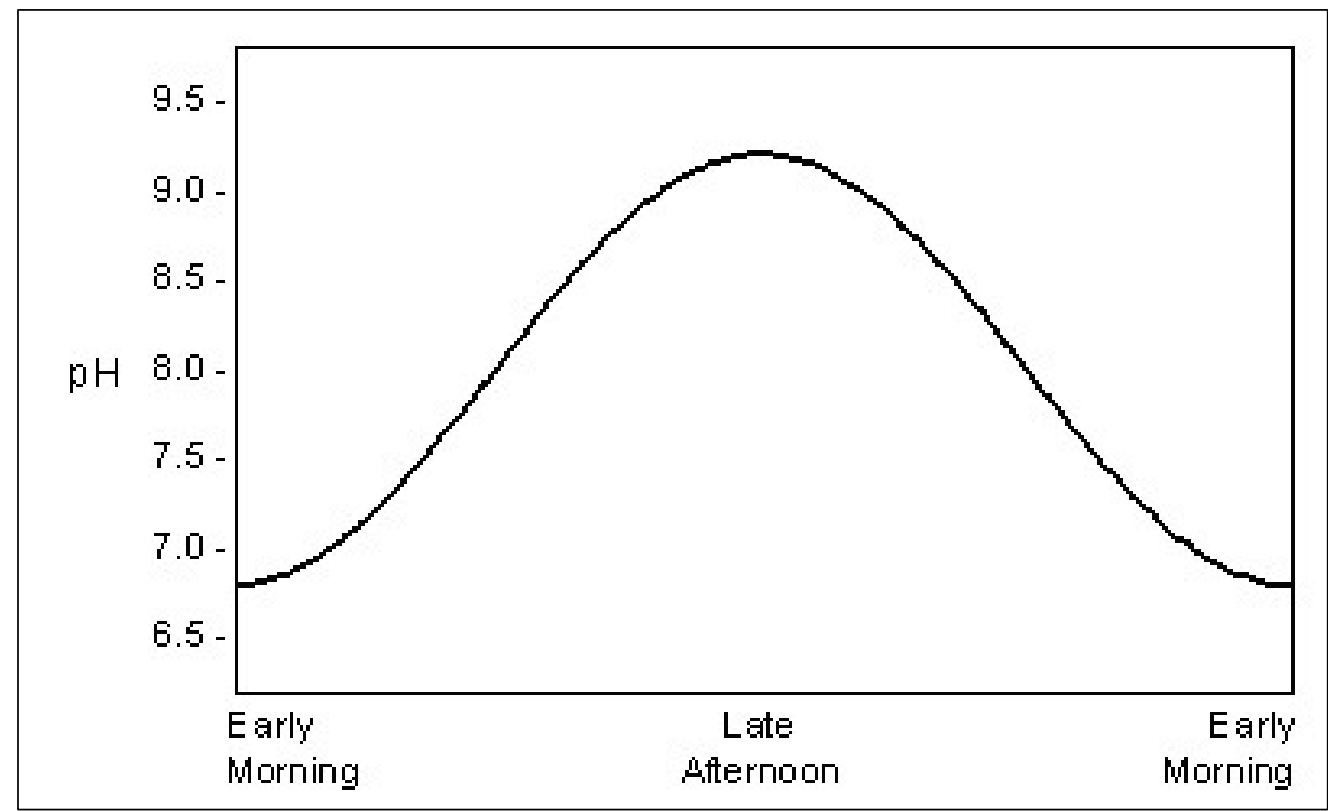

Ideal $\mathrm{pH}$ levels for fish are between 7 and 8; however, most fish can adapt to $\mathrm{pH}$ levels between 6 and 9 as long as there are no dramatic fluxes, exceeding $1.4 \mathrm{pH}$ units in either direction. When $\mathrm{pH}$ is low, fish become more susceptible to fungal infections. Additionally, at low $\mathrm{pH}$ levels calcium carbonate is reduced, therefore inhibiting shell growth. High $\mathrm{pH}$ levels can damage fish gills and skin (Fondriest Environmental 2016).

Aqueous $\mathrm{pH}$ level is also a concern as it is directly related to ammonia toxicity and the dissolution of metals (discussed below). At low and neutral $\mathrm{pH}$ levels, ammonia combines with water to produce the ammonium ion $\left(\mathrm{NH}_{4}+\right.$ ) (Equation 3). This form of nitrogen is not cytotoxic to aquatic life. However, at higher $\mathrm{pH}$ levels, the equation is reversed, and ammonia $\left(\mathrm{NH}_{3}\right)$ is released into the system. Unlike ammonium, ammonia is highly cytotoxic to aquatic organisms. This is an important consideration especially in eutrophic lakes, as pH-tolerant algae can dominate and form blooms that cause extreme swings in water $\mathrm{pH}$ throughout the day.

$$
\mathrm{NH}_{3}+\mathrm{H}_{2} \mathrm{O} \Leftrightarrow \mathrm{NH}_{4}^{+}+\mathrm{OH}
$$

\section{Anaerobic zones and noxious gases}

When DO is consumed in a lake, aerobic respiration will discontinue, and anaerobic respiration will begin to compensate. Anaerobic respiration uses 
electron acceptors other than oxygen to respire (Medina et al. 2014). Some reductive transformations result in the formation of noxious gases. In particular, reduction of sulfate can form hydrogen sulfide, and reduction of nitrate and nitrite can form ammonia. Both of these are gases that have foul odors and can have toxic effects at high concentrations or during prolonged exposures. Therefore, anaerobic zones are undesirable since they form reduced compounds like hydrogen sulfide and ammonia. Furthermore, in the sediment these compounds (sulfide and ammonia) can undergo aerobic, autotrophic reactions when the gases are re-exposed to oxygen. End products of these reactions include sulfuric and nitric acids. These acids can mobilize metals and nutrients, including phosphorus (Dunne and Reddy 2005; Reddy et al. 2005). For example, acidic conditions can drive the dissolution of iron phosphate $\left(\mathrm{FePO}_{4}\right)$, a mineral form in the sediment (from Dunne and Reddy 2005; Reddy et al. 2005):

$$
\mathrm{FePO}_{4}+\mathrm{H}^{+}+e^{-}=\mathrm{Fe}^{2+}+\mathrm{HPO}_{4}{ }^{2-}
$$

The elimination of anaerobic zones can reduce the production of gases like hydrogen sulfide and ammonia, which can then proportionately decrease the production of strong acids. Furthermore, in aerobic zones, metals like iron and aluminum are able to interact with and adsorb to phosphate increasing precipitation of phosphorus and therefore inhibiting nutrient release from sediment (Pastorok et al. 1982). On the contrary, oxygenation can also result in the stimulation of benthic macro-invertebrates, which can cause an increase in phosphorus release (Pastorok et al. 1982). However, the overall effect tends to be a reduction of phosphorous in the water column.

\section{Turbidity and sedimentation}

Turbidity is an optical characteristic of water and is an expression of the amount of light that is scattered by material in the water. It is a measure of the degree to which the water loses its transparency due to the presence of suspended particulates and to a lesser extent, color. Sedimentation refers to the tendency for particles in suspension to settle out of the water column (i.e, the terminal end of sediment transport). Much like nutrient transport into waterways, sediment is also deposited into lakes and reservoirs after storm events through the basic principles of erosion. Turbidity and sedimentation are directly related as soil erosion and sediment deposition can contribute to turbid conditions. Turbid 
conditions can be caused by natural and anthropogenic sources including influences from storms, riverine inflow, spawning/feeding activities, boating, etc. Both processes can be greatly accelerated by urban development/land-use and agriculture.

While the physical impact of sedimentation affects aquatic resources and degrades water quality, the effects are magnified when runoff carries contaminants associated with sediments. The effects of human-induced turbidity and resuspension are generally site specific and dependent on grain size and type, hydrological conditions, faunal influences, currents, water mass size, and configuration (Coen 1995). Furthermore, the costs associated with the control of sedimentation are increasing due to the necessity of dredging, special water treatment, and maintenance of shipping and stream channels (Glassner-Shwayder 1993).

Influxes of sediment have an impact on water quality and aquatic resources whether the sediment accumulates on the bottom or remains suspended in the water column (Schubel 1977). For example, turbidity directly effects light attenuation, which is essential to primary production of both algae and aquatic plants. Suspended particles also have the potential to release nutrients back into the system in a biologically available form for use by primary consumers. Therefore, suspended sediment and sediment deposition are important factors when considering ecological restoration options. 


\section{Aeration}

\section{Description}

Aeration has been routinely used to manage water quality in inland lakes and ponds (see Hudson and Kirschner [1997] for a practical summary of methods and benefits of lake aeration and mixing, as well as potential shortfalls). The primary goal of aeration is to increase DO in the water. This can be accomplished by air injection or mechanical mixing methods. In general, the process of aeration often promotes mixing in the lake or reservoir. The mixing process can also be beneficial in improving water quality in many cases (Chowdhury et al. 2014). Mixing can enhance aeration by allowing water trapped at the bottom of the lake to contact the surface for oxygen exchange, further improving DO levels. Cyanobacteria generally thrive in warmer water (Pearl and Huisman 2008) in the epilimnion just above the thermocline during highly stratified periods. The shear stress and reduction in temperature from mixing impacts the ability of these organisms to outcompete beneficial algae, which typically thrive in well-mixed cool systems. Additionally, mixing can improve sediment quality by removing reduced gases, like ammonia and hydrogen sulfide, from the benthic portions of a lake. However, mixing in shallow lakes may suspend fine benthic sediment. This could allow for increased nutrient release from these sediments, and water column warming due to the tendency of suspended solids to absorb solar radiation.

\section{Types of aeration}

Aeration systems can be divided into two types: surface and subsurface. Surface aeration relies on agitation of the surface to increase air entrainment. Surface aeration systems tend to require less energy and are very effective for relatively shallow ponds. However, the focus of the aeration is on the upper levels, so the benefits can be limited to levels below the thermocline. Three types of surface aerators are (1) fountains, which expels water into the air, allowing for air contact, (2) floating surface aerators, which disrupt water at the air-water interface, and (3) paddlewheel aerators, which use rotating wheels, paddles, or chains to churn water, creating aeration (Lyon et al. 2002). 
Subsurface aeration uses injection of air or oxygen into the subsurface, forming bubbles. The bubbles rise due to their buoyancy, and oxygen can diffuse through the bubble at the water interface. Bubble collapse can also be a means of transferring air into the water. There are three general types of subsurface aeration. Jet aeration uses the Venturi principle to aspirate air into the water. Briefly, the Venturi principle is the reduction in fluid pressure as a result of fluid flowing through a narrowed conduit. Coarse bubble aeration uses a nozzle to inject air bubbles on the order of 2 millimeters $(\mathrm{mm})$ into the water. Fine bubble aeration injects much smaller bubbles, which greatly improves air transfer. However, these require diffusers (which are typically made of silica, plastic, rubber, or ceramic) that can be prone to clogging. Subsurface injection has the advantage in that it more effectively aerates the entire water column. However, it is more costly to install, and generally uses more energy that surface aeration.

\section{Examples of subsurface aeration}

\section{Hydrodynamic cavitation}

Cavitation is an example of subsurface aeration that can provide oxygenation. The goal of cavitation is to inject unstable, collapsing bubbles. The bubble collapse can be an effective means for destroying microorganisms. In particular, cyanobacteria are susceptible to destruction because cavitation can result in the destruction of the gas vesicles that these organisms use to regulate their buoyancy in the water column (Medina et al. 2016b). In addition, cavitation can generate free radical oxygen species, such as superoxide and the hydroxyl radical, which can be useful for degrading contaminants. Studies have shown that these radical species can also degrade cyanobacteria toxins (Medina et al. 2016b). The goal of cavitation is not oxygenation, but this can occur as an additional benefit. The KRIA water treatment system is a reactor that couples cavitation with the injection of fine bubbles of charged oxygen (superoxide). In a mesoscale study, it was found that the KRIA treatment increased oxygen content from 8.63 to over $30 \mathrm{mg} / \mathrm{L}$ in 10 minutes of treatment and that the oxygen content was just over $29 \mathrm{mg} / \mathrm{L} 24$ hours after the treatment ceased (Medina et al. 2016c) 


\section{Laminar flow aeration}

Laminar flow aeration (LFA) is form of subsurface aeration, which is specifically designed to create circulation cells in the lake (Figure 7). In addition to oxygen provided by the subsurface bubbler, the system will ideally create surface currents that increase surface air entrainment. The idea is that these cells allow for more widespread aeration, particularly in the benthic portions of the lake, and also allow for toxic gases to be released into the atmosphere as opposed to accumulating in the sediments. LFA is described in Jermalowicz-Jones (2012).

Figure 7. Example of a LFA approach (adapted from a diagram prepared by Clean-Flo (https://www.clean-flo.com/inversion-oxygenation/).

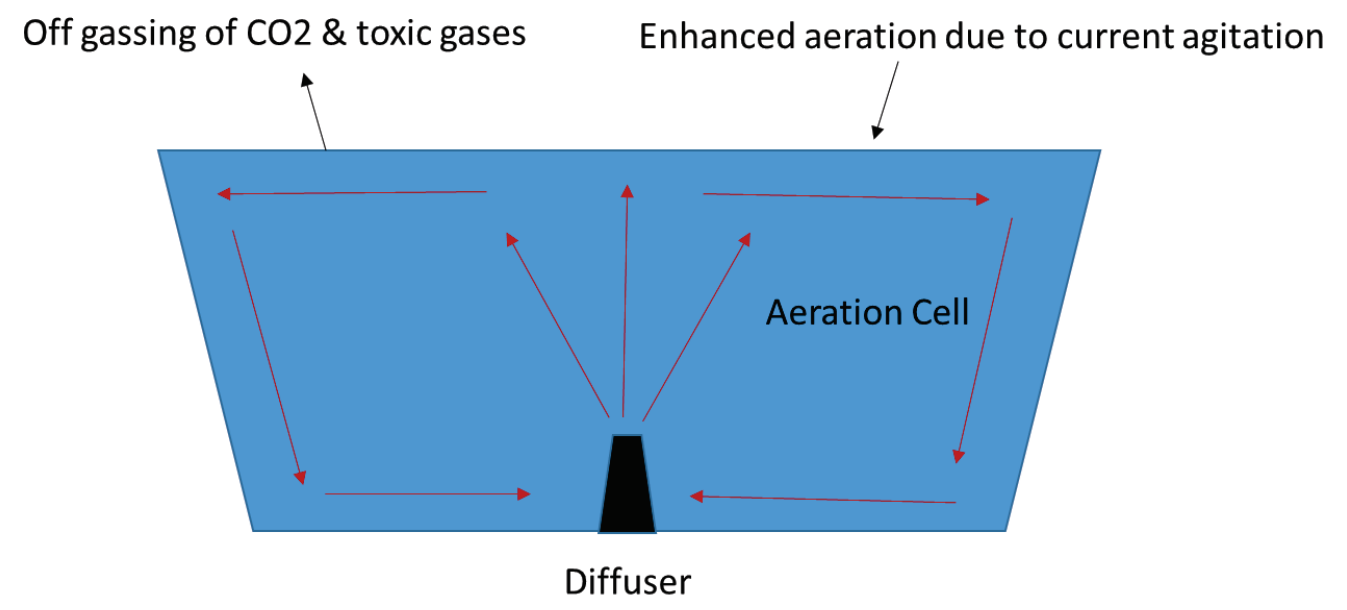

\section{Examples of aeration for ecological restoration}

Over 40 years ago, Weiss and Breedlove (1973) studied aeration as a means to break stratification in a lake in North Carolina. The method was successful in that the temperature profile of the lake became less stratified. The process also eliminated anaerobic zones in deeper portions of the lake and reduced cyanobacteria concentrations while promoting the growth of more beneficial algal forms. Evidence suggested that fish benefited from the process. However, the method had negligible impacts on oxygen diffusion with depth. Toetz (1981) reported that aeration was effective at improving water quality in two lakes in Oklahoma, particularly reducing $\mathrm{H}_{2} \mathrm{~S}$ and increasing DO concentration. The treatment also eliminated a small cyanobacteria bloom of Microcystis sp. However, there were some negative impacts, including a decrease in water clarity and an increase in general algal biomass. 


\section{Dredging}

\section{Description}

Dredging describes physical processes that remove sediment from lakes, rivers, and coastal areas. Dredging is most commonly used to improve or maintain navigation. However, it can also be used as a means of ecosystem restoration. In these cases, dredging can be used to promote habitat for native species or species of beneficial qualities, like sport fishing. Deepening a water body can also reduce sediment resuspension, improve water clarity, and reduce stored nutrient release. Dredging can be used to remove contaminants in the sediment and/or remove trash and debris in the benthos. Lewtas et al. (2015) conducted a review of phosphorus control methods for lakes and found that "Dredging can control both algae and macrophytes and can restrict internal nutrient loading by eliminating the enriched sediment layer or sediments contaminated with toxic substances."

Dredging is particularly effective if the upper layer has become especially concentrated with nutrients. Dredging can also be beneficial by removing undesirable macrophytes and cyanobacterial akinetes (a dormant stage that, under optimal physical conditions, can provide seed populations for bloom initiation). Photosynthetic growth from macrophytes and algae can be minimized if the sediment layer is below the photic zone and/or if dredging occurs during light- (and temperature-) limited times of the year.

\section{Types of dredging}

There is a wide range of dredging methods that can be used. Suction methods use powerful vacuum effects to suck up sediments. These processes can be enhanced using cutting devices or augers. Digging devices can also be used for dredging, which includes standard buckets, clamshell buckets, and backhoes. In some cases, powerful water jets can be used to suspend the sediment, which can then be recovered at the surface using skimming equipment. Of these approaches, suction approaches are most useful for ecological restoration because the suction process limits sediment resuspension in the water column. 


\section{Examples of dredging for ecological restoration}

Whiten and Twohig (2007) describe an ecological restoration of Mussachuck Creek, a small watershed in Rhode Island. Sediment buildup had allowed an invasive reed, Phragmites australis, to infest a portion of the creek that flowed through a golf course. Dredging changed water flow conditions (particularly allowing the reestablishment of tidal flow), which promoted growth of native vegetation at the expense of $P$. australis. Kong et al. (2013) describe modeling for a lake in China (Lake Chaohu) for strategies to reduce phosphorus loading. The model predicted that sediment dredging would reduce phosphorus content and assist in minimizing algal blooms. However, the model indicated that dredging would not be as effective as a water management approach called Ecological Economy Water Level, which focuses on reducing water level in the spring. Yu et al. (2016) discuss a project to control nitrogen flux for Lake Taihu in China. The study provided strong support that dredging can reduce nutrient availability as nitrogen availability overall declined. The decline was primarily due to a reduction of ammonia, although nitrate actually increased. The decrease was correlated to a decline in biodiversity of microbial organisms. Lewtas et al. (2015) describe two applications of dredging for nutrient control in detail-Lake Trummen in Sweden and Lilly Lake, Wisconsin. At Lake Trummen, the sediments had been impacted by a wastewater treatment discharge. Dredging of approximately 50 centimeters using a special suction that focused on the removal of soft sediments was able to change the nature of the sediment/water interface, resulting in $90 \%$ reduction of total phosphorus in the surface water. Although there has been some rebound in nutrient concentrations, the nutrient levels were still suppressed 40 years after the dredging. The sewage and industrial waste outfalls were diverted to control nutrient inputs, and a fish management program was also instituted. Dredging was conducted in 1978 and 1980 in Lilly Lake, which suffered from infilling with sediment and aquatic plants. From 1981 to 1989, total phosphorus declined from 14 to $9 \mu \mathrm{g} / \mathrm{L}$, and total nitrogen dropped from 1.1 to $0.8 \mathrm{mg} / \mathrm{L}$. 


\section{Direct Comparison of Aeration and Dredging}

Table 3. A comparison of methods by environmental factor.

\begin{tabular}{|c|c|c|}
\hline Factor & Aeration & Dredging \\
\hline $\begin{array}{l}\text { Dissolved } \\
\text { Oxygen }\end{array}$ & $\begin{array}{l}\text { Causes an increase in DO concentrations in the } \\
\text { treated area by directly adding air or oxygen to } \\
\text { the system. Aeration can also work to } \\
\text { dissipate/disperse thermal stratification and } \\
\text { therefore can allow for the dissolution of } \\
\text { atmospheric oxygen into the hypolimnion. }\end{array}$ & $\begin{array}{l}\text { Dredging has minimal influence on DO } \\
\text { concentrations. In actuality, dredging can } \\
\text { cause a decrease in DO owing to an } \\
\text { increase in bacterial productivity from } \\
\text { the resuspended nutrients released from } \\
\text { the sediment (discussed below). }\end{array}$ \\
\hline Fish & $\begin{array}{l}\text { Can have both positive and negative impacts on } \\
\text { fish habitat. First, aeration can increase the DO } \\
\text { concentration, which is especially important } \\
\text { during times of stratification. Second, aeration } \\
\text { can cause water column mixing and } \\
\text { destratification, which can allow fish to inhabit } \\
\text { the entire lake. However, in some cases, } \\
\text { destratification can be undesirable for cold-water } \\
\text { species since it can actually warm deeper water } \\
\text { where these cold-water species thrive. } \\
\text { Additionally, aeration can suspend small particles } \\
\text { from the sediment layer, which can absorb heat } \\
\text { from the sun and cause an increase in water } \\
\text { temperatures. }\end{array}$ & $\begin{array}{l}\text { Dredging has an impact on fish spawning } \\
\text { as it can remove native vegetation } \\
\text { required for spawning habitats. However, } \\
\text { it can also increase spawning activities } \\
\text { by removing invasive macrophytes such } \\
\text { as Eurasian watermilfoil that impede fish } \\
\text { spawning activities by blocking habitat } \\
\text { access. Similar to aeration, suspended } \\
\text { particles from dredging activities can } \\
\text { indirectly heat the water column causing } \\
\text { problems for cold-water fish species. }\end{array}$ \\
\hline $\begin{array}{l}\text { Organic } \\
\text { Matter/Muck }\end{array}$ & $\begin{array}{l}\text { Aeration can improve water quality by increasing } \\
\text { aerobic degradation of organic compounds and } \\
\text { minimizing anaerobic reactions. }\end{array}$ & $\begin{array}{l}\text { Dredging can physically remove muck } \\
\text { and organic matter. }\end{array}$ \\
\hline $\begin{array}{l}\text { Phytoplankton } \\
\text { and } \\
\text { Cyanobacteria }\end{array}$ & $\begin{array}{l}\text { Aeration itself is believed to have little direct } \\
\text { impact on phytoplankton, although it may affect } \\
\text { nutrient availability and mixing. Mixing can have a } \\
\text { beneficial effect on reducing algae biomass by } \\
\text { changing its residence time in the photic portions } \\
\text { of the lake. This is particularly effective in } \\
\text { relatively deep lakes. Furthermore, the } \\
\text { suppressive effect is often most effective on } \\
\text { hazardous cyanobacteria, because these } \\
\text { organisms are particularly adapted to thrive in } \\
\text { highly stratified systems. Using aeration, studies } \\
\text { have observed shifts from undesirable } \\
\text { cyanobacteria to healthier phytoplankton } \\
\text { assemblages dominated by green algae (Pastorok } \\
\text { et al. 1982). However, the technique can be } \\
\text { ineffective for shallower lakes and might even be } \\
\text { counterproductive if mixing results in the } \\
\text { suspension of nutrients from the sediments. } \\
\text { Additionally, improperly managed aeration could } \\
\text { resuspend the benthic population of } \\
\text { cyanobacteria and thus perpetuate HAB events. }\end{array}$ & $\begin{array}{l}\text { The impacts of dredging on } \\
\text { phytoplankton and cyanoHAB occurrence } \\
\text { have not been well studied, especially in } \\
\text { freshwater systems. However, dredging } \\
\text { has the potential to resuspend the } \\
\text { benthic population of cyanobacteria and } \\
\text { either remove these cells from the } \\
\text { system or resuspend cells into the } \\
\text { pelagic zone where they can propagate } \\
\text { cyanoHAB events. Much like aeration, } \\
\text { dredging can resuspend particles } \\
\text { causing the release of bound nutrients } \\
\text { that could stimulate cyanoHAB events. }\end{array}$ \\
\hline
\end{tabular}




\begin{tabular}{|c|c|c|}
\hline Factor & Aeration & Dredging \\
\hline Aquatic Plants & $\begin{array}{l}\text { Aeration can have a dual impact on aquatic } \\
\text { plants. First, it can directly cause plant } \\
\text { fragmentation and dispersal and so could } \\
\text { damage native and invasive macrophytes. A major } \\
\text { concern with this method is the dispersal of } \\
\text { undesired plants thus perpetuating the } \\
\text { problem/invasion in lakes/reservoirs. On the } \\
\text { other side, aeration could increase water } \\
\text { turbidity, which would decrease light attenuation } \\
\text { and limit the light available to macrophytes for } \\
\text { photosynthesis, but it would also cause a release } \\
\text { of stored nutrients that could readily be } \\
\text { consumed by macrophytes. Studies have } \\
\text { consistently shown that aeration can partially } \\
\text { reduce the growth and biomass of nuisance plant } \\
\text { species. For example, Jermalowicz-Jones (2016) } \\
\text { found aeration retarded growth of Eurasian } \\
\text { watermilfoil in a Michigan lake. Additionally, } \\
\text { Cooley et al. (1980) showed that aeration } \\
\text { reduced growth of the Eurasian watermilfoil by } \\
20 \% \text {. However, any invasive species treatment } \\
\text { that does not control } 85 \% \text { of the target population } \\
\text { is generally considered unacceptable from a } \\
\text { management perspective (pers. comm. Kurt } \\
\text { Getsinger 5/2017). Additionally, aeration may not } \\
\text { feasibly be applied over large areas for controlling } \\
\text { plant growth. Last, anaerobic zones can increase } \\
\text { iron dissolution in sediments (see below), which is } \\
\text { essential to the productivity of nuisance plant } \\
\text { species. }\end{array}$ & $\begin{array}{l}\text { Dredging would physically remove plant } \\
\text { biomass and therefore could be } \\
\text { beneficial when dredging areas that have } \\
\text { invasive species; however, in the process } \\
\text { dredging would cause the physical } \\
\text { fragmentation of plants that could lead } \\
\text { to dispersal and increased invasion. The } \\
\text { removal of native plants could also be } \\
\text { undesired as this frees up space for } \\
\text { invasive plants to establish and removes } \\
\text { valuable food and habitat from the } \\
\text { system. Dredging has a minimal impact } \\
\text { on nutrient status so would not have the } \\
\text { same added benefit of removing iron } \\
\text { from the system as aeration has. Last, } \\
\text { dredging to control plant growth can be } \\
\text { costly especially over large areas of } \\
\text { infestation. }\end{array}$ \\
\hline Nutrients & $\begin{array}{l}\text { Aeration can cause an increase in the desorption } \\
\text { of sediment-bound nutrients, mainly } \\
\text { phosphorous, through increased surface area } \\
\text { contact in the water column after resuspension. }\end{array}$ & $\begin{array}{l}\text { Dredging can also increase solubilization } \\
\text { of nutrients, especially phosphorous but } \\
\text { to a much less extent than aeration. }\end{array}$ \\
\hline $\begin{array}{l}\text { Anaerobic } \\
\text { Zones \& } \\
\text { Noxious } \\
\text { Gases }\end{array}$ & $\begin{array}{l}\text { By supplementing the system with a direct supply } \\
\text { of oxygen, aeration can minimize or eliminate the } \\
\text { anaerobic conditions that cause noxious gas } \\
\text { production, thereby eliminating the formation of } \\
\text { strong acids that would interact with and cause } \\
\text { the dissolution of nutrients and metals. }\end{array}$ & $\begin{array}{l}\text { Studies have not shown that dredging } \\
\text { has a direct impact on the oxygen status } \\
\text { of water bodies. The production of } \\
\text { aerobic or anaerobic conditions following } \\
\text { dredging is likely highly site specific and } \\
\text { is dependent on the activity of } \\
\text { autotrophs within the system. However, } \\
\text { dredging could physically remove } \\
\text { anaerobic pockets in the sediment } \\
\text { and/or re-expose deeper anaerobic } \\
\text { pockets to oxygenic conditions. }\end{array}$ \\
\hline Turbidity & $\begin{array}{l}\text { Aeration can have a negative effect on water } \\
\text { clarity if the technique causes the suspension of } \\
\text { particulates from the sediment. This effect can be } \\
\text { particularly troublesome in shallow lakes. Careful } \\
\text { control of aeration rates and locations can } \\
\text { minimize and reduce this effect. }\end{array}$ & $\begin{array}{l}\text { Depending on the type of dredging, it can } \\
\text { have similar effects on water clarity as } \\
\text { aeration. }\end{array}$ \\
\hline
\end{tabular}




\begin{tabular}{|c|c|c|}
\hline Factor & Aeration & Dredging \\
\hline Sedimentation & $\begin{array}{l}\text { The impacts of aeration on sediment reduction } \\
\text { are controversial. For example, a report on Indian } \\
\text { Lake suggested that LFA resulted in less muck, } \\
\text { deepening of the lake, and establishment of a } \\
\text { harder bottom (Indian Lake Improvement } \\
\text { Association 2016). However, Engstrom and Wright } \\
\text { (2002) did not find a difference in the average } \\
\text { sedimentation accumulation during a comparison } \\
\text { study in } 10 \text { Minnesota lakes. Nor did the study } \\
\text { find any evidence of differences in sediment } \\
\text { composition in these lakes. Aside from having } \\
\text { conflicting results in sediment removal there is } \\
\text { potential for aeration to reduce anaerobic zones. } \\
\text { For example, it has been hypothesized that by } \\
\text { enhancing aerobic biological activity, aeration will } \\
\text { promote enhanced degradation of organic matter, } \\
\text { thereby indirectly reducing sediment thicknesses. } \\
\text { Ultimately, aeration may have some implications } \\
\text { in sediment reduction though this is likely highly } \\
\text { site specific. }\end{array}$ & $\begin{array}{l}\text { Since the principle of dredging is the } \\
\text { physical removal of sediment, dredging } \\
\text { would have obvious benefits on } \\
\text { sediment reduction. Additionally, the } \\
\text { lake/reservoir would benefit from the } \\
\text { removal of hypoxic/anoxic sediments. } \\
\text { Thus stimulating oxygenic organic matter } \\
\text { degradation. Realistically, neither } \\
\text { method addresses the influx of material } \\
\text { into the system, so both would need to } \\
\text { be repeated routinely to minimize } \\
\text { sedimentation. }\end{array}$ \\
\hline
\end{tabular}




\section{Koontz Lake Assessment}

\section{Aeration}

\section{Decreasing phosphorous}

Aeration at Koontz Lake would likely have a beneficial effect on phosphorus levels. Stratification typically results in the formation of anaerobic zones. It is estimated that an anaerobic zone covers approximately 40 acres (16 hectares) of the lake. Removal or even reduction of this area would lower levels of reduced gases, which can cause acid production and metal/nutrient releases. There is a potential drawback-depending on rates of new sedimentation and phosphorus addition into the lake, the establishment of a new equilibrium could eventually become exhausted (Lewtas et al. 2015). Furthermore, it is suggested that LFA be used in deeper sections of the reservoir to minimize desorption of nutrients from resuspended particles.

\section{Controlling invasive species}

The LFA approach might have beneficial effects on Eurasian watermilfoil infestations. Several studies have found that aeration/mixing commonly results in decreases ( $20 \%)$ in milfoil and other noxious aquatic weeds. Though from a management perspective, this is not an ideal stand-alone treatment; it has several attributes that make it ideal for combination management strategies. For example, aeration could reduce invasive species indirectly by decreasing the anaerobic zone and therefore also decreasing reduced gases, as it is likely that these weeds are more resistant to reduced gases than desirable, native species. It is recommended that LFA be performed in relatively deep portions of the lake to minimize sediment resuspension and nutrient desorption that would directly impact plant species.

\section{Reduction in sedimentation}

LFA is not likely to have any direct positive impacts on reduction of sediment or muck thickness. There are some studies that suggest that this can occur, but the most comprehensive studies seem to indicate that this is not likely. 


\section{Cost and frequency}

LFA can be fairly expensive depending on run-time and frequency. It has been found that relatively modest energy inputs can create sufficient mixing (Weiss et al. [1973] used motors of less than 1 horsepower). This means that the equipment can be light and low cost (relatively) and that energy costs are usually reasonable over short periods. Additionally, it is usually possible to get positive benefits even if the system operates intermittently. However, LFA systems need to be operated annually, so there is a continuous cost in energy and maintenance, which can increase (Lewtas et al. 2015). At least one technology, the SolarBee system (a subsidiary of Medora Corporation, Dickenson, ND, http://www.medoraco.com/ [be aware that this is a vendor site]), uses solar power to create mixing, reducing energy costs. However, there is anecdotal evidence of unsatisfactory application of SolarBee systems, and it is probably best used for limited area of potential control.

\section{Dredging}

\section{Decreasing phosphorous}

The impact on phosphorus is rather complex. Dredging would have some obvious beneficial effects in reducing phosphorous by deepening the lake, reducing the potential for nutrient desorption. If dredging does reach the glacial till base, then it should be successful at removing most of the phosphorus-laden sediment, therefore reducing nutrient flux in these areas. However, complete removal of sediment is not likely as the bedrock level would likely be uneven. Additionally, complete sediment removal is not recommended as sediment not only acts as a source for nutrients but also a sink. Complete removal of sediment could result in higher pelagic phosphorous concentrations, due to external loading, at least until new sediment is deposited, which will eventually occur. However, the rate of sedimentation is unclear. Additionally, the dredging process could cause a resuspenion in sediment allowing for desorption of nutrients and a flux of phosphorous into the water column (Lewtas et al. 2015).

\section{Controlling invasive species}

In the near term, dredging would also remove habitat for milfoil and provide relief in terms of noxious weed growth and dispersal. A dredging depth of approximately $7 \mathrm{ft}$ appears to be deep enough to limit regrowth of the milfoil due to the increase in light attenuation with depth. However, 
dredging could cause macrophyte fragmentation and increase dispersal. Additionally, dredging can have significant impacts on the benthos by physically removing a portion of the lake. Dredging can be beneficial in removing muck and invasive species and providing new habitat for native macrophytes to establish; however, it could also directly remove fish spawning habitat and a primary food source from the system, so it may be best to avoid dredging during active fish-spawning periods. Therefore, it is suggested that dredging occur late in fall/early in spring to minimize contact with vegetative parts of the plant, to remove dormant stages prior to the growing season, and to minimize the impact on non-target species like fish spawning activities. Since dredging completely disrupts the benthic environment, ecological recovery could be slow and may undergo a series of phases before full recovery occurs.

\section{Reduction in sedimentation}

The dredging proposed at Koontz Lake would focus on the removal of material from the shallow portion of the lake from $3 \mathrm{ft}$ to $7 \mathrm{ft}$ depth (USACE 1998). The sediment would be removed hydraulically, meaning it would be removed as a slurry. This would cover approximately 170 acres of the 346 acre lake and would amount to approximately 195,300 cubic yards $\left(\mathrm{yd}^{3}\right)$ of material. Some impacts on turbidity are expected but would be minimized as best as possible.

Dredging produces a by-product: dredged sediment. In some cases, this is treated as a waste product (e.g., placement in a confined disposal facility). However, in many cases, if cleared of chemical and biological contaminants, sediment can be beneficially reused. Landin et al. (1994) outlines a variety of possible uses including wetland restoration, agricultural soils, and even as a raw material for geotextiles. If, as expected, the dredged sediment is free of contaminants, it applied to farmland upland of the lake. A cost estimate of \$2.5 million was obtained for dredging by Eddy Pump Company for the portions of depth $7 \mathrm{ft}$ or less, which would involve the removal of $195,300 \mathrm{yd}^{3}$. Dredging may have to be reapplied over time as the lake refills with sediment. 


\section{Alternative Technologies}

There are some other interesting technologies that could be used in a lake like Koontz Lake. This section focuses on control of phosphorus. There are other issues, but they either have limited alternatives or are well covered in other documents. In terms of sediment removal, dredging is a unique option. Control of CyanoHAB in reservoirs is well covered in Herman et al. (2017).

\section{Phoslock}

Recently, processes involving binding of phosphorus in the sediment is a developing technology. The concept is that if phosphorus is tightly bound in the sediment, it is unavailable for mass transfer into the water column. Reduced iron has been shown to be effective at binding phosphorus in sediments and thereby regulating its concentrations in the water column (Boeers et al. 1992; Orihel et al. 2015). Combining reduced iron in an electrode system has also shown promising results. Phoslock (lanthanum modified bentonite) is a product that has been shown to bind phosphorus in sediments, reducing its availability in the water column (McNabb 2011; Bishop et al. 2014). A study at Mason Lake in Southern California saw total phosphorus in the water drop from $0.82 \mathrm{mg} / \mathrm{L}$ to $0.41 \mathrm{mg} / \mathrm{L}$, although this level is still above levels for "highly eutrophic" lakes (o.1 $\mathrm{mg} / \mathrm{L}$ ) (McNabb 2011). In another study conducted on a shallow lake in Florida (Pine Lake, Palm Beach County), there was a 30\% reduction of total phosphorous in the water column after a Phoslock application (SePRO 2014). In yet another application at Laguna Niguel Lake in Southern California, phosphorus concentration in the water column was again removed, and a cyanobacterial bloom that was measured prior to application had dissipated (Bishop et al. 2014; SePRO 2015). However, the beneficial effects of Phoslock diminish over time, and in some applications relatively quickly, within a year or two. For example, a report on the Pine Lake application just 1 year after treatment noted that phosphorus levels in the water column were approaching levels before the treatment (Palm Beach County Board of Commissioners 2015). Another application at Lake Lorene, Washington, stated that while Phoslock application resulted in elimination of cyanobacterial blooms the year it was applied, a new bloom was reported the year after (The Federal Way Mirror 2014). The cause might have simply been new inputs of phosphorus; however, Phoslock applications can be expensive, on the order of $\$ 40,000$ per application at 
Lake Lorene, which is approximately 8 surface acres in area (The Federal Way Mirror 2014). In fairness, most available information on phoslock application is given by SePRO or by groups funded by them.

Phoslock would have a similar impact on aquatic plants as it has on microalgae as both require phosphorous for growth. However, Phoslock may have a more profound impact on aquatic plants as they are embedded in the benthos where the Phoslock would settle. Furthermore, collapsing aquatic plants may enhance algal growth by releasing nutrients back into the water column; it may also stimulate bacterial productivity through dissolved organic matter and thereby reduce dissolved oxygen levels. Therefore, in macrophyte dominated systems, the reduction of sediment bound phosphorus is complex and requires an understanding of the ecosystem in which it will be applied to guide the timing, quantity, and frequency of Phoslock application for successful phosphorous reduction with minimal off-target effects (Kronvang 2013).

Iron

The presence of iron in lake systems can greatly impact the behavior of the phosphorus cycling. The natural presence or the addition of iron (oxides) has the capabilities of increasing the formation of stable phosphate minerals in lake sediments (Boers et al. 1992; Smolders et al. 2001; Parker 2004; Hoverson 2008; Orihel et al. 2015; Martins et al. 2014). Iron-rich sediment can remove biologically available phosphate by sorption to oxidized metals. Oxidized iron-phosphate complexes, for example, can settle and precipitate out of the epilimnion (Parker 2004), thus, greatly reducing phosphorus from the water column.

There is not a significant amount of information on how iron can be added full scale into lacustrine sediments. One example is provided by Engstrom (2002), which indicates that in 1987 a ferric chloride feed system was added to the Mississippi River pumping station, and two hypolimnetic aerators were installed in Vadnais Lake. The injected iron scavenges dissolved phosphorus from the river water and precipitates it to the sediments of Charley and Pleasant lakes while the hypolimnetic aerators introduce both air and ferric chloride to the bottom waters of Vadnais Lake to inhibit internal phosphorous loading during summer stratification. Presumably, iron can be added to dredged sediments, which are then reapplied, or metallic iron can be added into the water column and allowed to settle on the sediment surface. 


\section{Aluminum sulfate}

Alum, or aluminum sulfate, is a highly effective flocculant, and it is commonly used in water treatment to remove metals and turbidity. Alum is also very effective at binding to and precipitating out phosphate and has been used in wastewater treatment for this purpose. Alum has also been used to remove phosphorus from the water column in lakes suffering from eutrophic conditions (Cooke et al. 1978; WDNR 2003).

When exposed to water, alum will react with water to form aluminum hydroxide, which is a fluffy precipitate called floc (Equation 5 ). The aluminum hydroxide will react with dissolved phosphorus to form ammonia phosphate (Equation 6). Aluminum phosphate is insoluble in most aquatic conditions. The aluminum hydroxide/phosphate floc will agglomerate and settle on the sediment. The settled aluminum hydroxide can act as a reactive barrier to trap phosphate that may be released from the sediment.

$$
\begin{gathered}
\mathrm{Al}_{2}\left(\mathrm{SO}_{4}\right)_{3}+6 \mathrm{H}_{2} \mathrm{O}=2 \mathrm{Al}(\mathrm{OH})_{3}+3 \mathrm{SO}_{4}{ }^{2-}+6 \mathrm{H}^{+} \\
\mathrm{Al}(\mathrm{OH})_{3}+\mathrm{PO}_{4}{ }^{3-}=\mathrm{AlPO}_{4}+3 \mathrm{OH}^{-}
\end{gathered}
$$

Alum is one technology that has been studied systematically. Welch and Cooke (1999) summarized studies on lakes throughout the United States. They found that treatments were effective for 6 of 9 shallow lakes studied. For lakes in which phosphorus was primarily from internal sources, reductions averaged $80 \%$, and treatment has been reported to limit phosphorus in the water column for as long as 8 years. Discussions with Tony Clyde (2017, Personal Communication) indicate that his experience is that alum treatment tends to be exhausted in a much shorter time, 1 to 2 years. He also indicated that treatments can be very expensive. In addition, heavy macrophyte growth could defeat treatment and for lakes with substantial external loading (such as from influent streams or irrigation return flows) the long-term effectiveness was substantially reduced (Welch and Cooke 1999).

Other flocculants can also be used effectively in a similar manner. In particular, ferric chloride $\left(\mathrm{FeCl}_{3}\right)$ can also be used to remove phosphate, creating iron phosphate $\left(\mathrm{FePO}_{4}\right)$ as an insoluble product. 


\section{Nitrogen}

A primary focus of this document is on the control of phosphorus to limit algal blooms in general. Of particular concern are CyanoHAB events, which result in the release of undesirable toxins. These events are stimulated by high concentrations of phosphorus. However, Harris et al. (2016) investigated a unique approach. Instead of removing phosphorus, their study investigated the concept of adding additional nitrogen to the system. The idea was to shift the nutrient regime to that favoring other algae that are less harmful or even beneficial. A laboratory study and comparison of field data suggest that this approach could be useful, although an actual field application has not been conducted to collect data. 


\section{Recommendations for Koontz Lake}

The major concerns for Koontz Lake are (1) controlling phosphorous, (2) controlling Eurasian watermilfoil in shallow areas of lake, and (3) reducing sedimentation/in-filling and controlling muck in shallow portions of the lake. Conditions at Koontz Lake suggest that aeration/mixing could eliminate anaerobic areas, which would address phosphate issues, and aeration has also been shown to be somewhat effective for noxious plants, though not as a sole treatment strategy but would probably not be effective for management of sediment/muck accumulation. However, considering that all three concerns are nearshore, it is not recommended to use LFA as this may perpetuate water quality problems. Furthermore, dredging would directly address the sediment/muck issue but has moderate potential for addressing the other two issues, at least in the near term. This suggests that dredging is the best immediate option for sediment reduction.

In the long term, the best option for controlling nutrient levels and invasive species growth is to develop a best management plan to reduce external nutrient loading, specifically phosphorous loading. Nutrient control can be challenging because there can be a significant number of sources; however, it can be very effective. One of the most welldocumented examples was the recovery of Lake Erie, which was highly eutrophic in the early 1970s (Jeanneret 1989). Although it can still have issues with cyanobacterial blooms (Medina et al. 2016b), nutrient control measures have reduced dissolved phosphorus substantially, and walleye fish, which were non-existent in the 1970s, had returned in the late 1980 os (Jeanneret 1989). The Koontz Lake Association has developed such a plan to include the better management of septic sewage systems by residents near and surrounding the lake and to encourage residents to develop their own means of improving water quality on their properties (JFNew 2010). However, these often take time (on the order of years, possibly decades), and there is an immediate need for sediment reduction coupled to decreased nutrient loading and primary production. With this in mind, an integrated treatment strategy might be considered-coupling dredging with LFA and/or phosphorus control. In this approach, aeration could limit phosphorus rebound and reduce primary productivity from cyanobacteria and invasive species while addressing unpleasant 
anaerobic gases generated from the deeper portions of the lake and stimulating aerobic bioactivity at the lake bottom.

Long-term management will probably be necessary for Koontz Lake. However, a study by Grochowska et al. (2017) on a lake in Poland found that after ecological restoration measures were discontinued, water quality did not degrade to the original level. After 10 years of nontreatment, the lake has maintained water quality within desirable levels. 


\section{Summary}

The purpose of Table 4 is to provide easily identifiable information to ascertain the best method for the ecosystem in question regarding the most important environmental factors. For example, if the primary concern for resource managers in their reservoir is maintaining DO levels to minimize anaerobic/hypoxic zones, then the resource manager should perhaps consider using LFA over dredging. LFA directly injects oxygen into the system and stimulates healthy microbial communities and destratification, thus helping to restore and stabilize the ecosystem for the long term. For more detailed information regarding each environmental factor, see Table 3 .

Table 4. Summary of impacts on environmental factors.

\begin{tabular}{|c|c|c|}
\hline Factor & Aeration & Dredging \\
\hline $\begin{array}{l}\text { Dissolved } \\
\text { Oxygen }\end{array}$ & Increase & No change \\
\hline Fish & $\begin{array}{l}\text { Positive: increase DO and habitat } \\
\text { Negative: water column warming }\end{array}$ & $\begin{array}{l}\text { Positive: remove invasive plants to } \\
\text { provide habitat } \\
\text { Negative: removal of } \\
\text { spawning grounds }\end{array}$ \\
\hline $\begin{array}{l}\text { Organic } \\
\text { Matter/Muck }\end{array}$ & Degradation of organic matter & Removal of muck \\
\hline $\begin{array}{l}\text { Phytoplankton and } \\
\text { Cyanobacteria }\end{array}$ & $\begin{array}{l}\text { Positive: change residence time in } \\
\text { photic zone } \\
\text { Negative: Resuspension of } \\
\text { nutrients and resting cells }\end{array}$ & Not well studied \\
\hline Native Aquatic Plants & $\begin{array}{l}\text { Positive: increased dispersal and } \\
\text { nutrient re-suspension } \\
\text { Negative: decreased light } \\
\text { attenuation }\end{array}$ & $\begin{array}{l}\text { Positive: increased dispersal } \\
\text { Negative: provides new } \\
\text { habitat for invasive species to fill-in }\end{array}$ \\
\hline $\begin{array}{l}\text { Invasive Aquatic } \\
\text { Plants }\end{array}$ & $\begin{array}{l}\text { Positive: decreased light } \\
\text { Attenuation limiting growth } \\
\text { Negative: increased dispersal and } \\
\text { nutrient resuspension. Adapted growth } \\
\text { at decreased light intensities. }\end{array}$ & $\begin{array}{l}\text { Positive: physical removal of plant } \\
\text { Negative: increased dispersal }\end{array}$ \\
\hline Nutrients & Increase in shallow systems & No major impact \\
\hline $\begin{array}{l}\text { Anaerobic Zones \& } \\
\text { Gases }\end{array}$ & Decrease & $\begin{array}{l}\text { Removal of hypoxic/anoxic } \\
\text { sediment }\end{array}$ \\
\hline Turbidity & Increase in shallow systems & Increase \\
\hline Sedimentation & No measurable impact & Decrease \\
\hline
\end{tabular}




\section{Conclusions}

Based on this study, the following conclusions can be derived.

\section{Aeration}

- Aeration can address a wide range of ecological issues, including oxygen depletion, nutrient availability, and fish habitat.

- Through a range of processes, aeration can be effective at controlling Cyano/HABs in many cases.

- Aeration may beneficially improve sediment accumulation, but ultimately, dredging may be required.

\section{Dredging}

- Dredging is the most effective approach for addressing sediment accumulation in a lake/reservoir.

- Dredging would remove invasive plants where applied and would create a deeper bottom, which can inhibit the colonization of many invasive species. However, it also can break up plants, which can lead to new infestations as most nuisance invasive species can vegetatively reproduce.

- Dredging could address nutrient issues, but it can also make these situations worse.

- Dredging is a temporary solution; sediment will eventually reaccumulate assuming other corrective measures are not taken.

\section{Alternative technologies}

- Additives (Phoslock or iron) may be effective at limiting phosphorus by increasing the formation of mineral species in the sediment, but the applications can be expensive and may have to be reapplied.

- Alum or ferric iron treatments can remove phosphorus from the water column and limit sediment contributions, but some conditions (excessive macrophytes and/or external phosphorus sources) can limit treatment effectiveness. 


\section{References}

Bartsch, A. F. 1972. Role of Phosphorus in Eutrophication. EPA-R3-72-001. United States Environmental Protection Agency. https://nepis.epa.gov/Exe/ZyNET.exe/91015953.txt?ZyActionD=ZyDocument\&Client=EPA\&Inde $\underline{x}=$ Prior\%20to\%201976\&Docs $=\& Q$ uery $=\&$ Time $=\&$ EndTime $=\&$ SearchMethod $=1 \&$ TocRestrict $=n \& T$ oc $=\&$ TocEntry $=\& Q$ Field $=\& Q$ FieldYear $=\& Q$ FieldMonth $=\& Q$ FieldDay $=\&$ UseQField $=\& I n t Q F i e l d 0 p=0$ \&ExtQField O $=0$ \&XmlQuery $=\&$ File $=D \% 3 A \% 5$ CZYFILES $\% 5$ CINDEX\%20DATA $\% 5 C 70 T H R U 75 \% 5 C T X$ T\%5C00000018\%5C91015953.txt\&User=ANONYMOUS\&Password=anonymous\&SortMethod=h $\% 7 \mathrm{C}-$

\&MaximumDocuments=1\&FuzzyDegree=0\&ImageQuality=r75g8/r75g8/x150y150g16/i425\&Di splay=hpfr\&DefSeekPage $=x \&$ SearchBack=ZyActionL\&Back=ZyActionS\&BackDesc $=$ Results\%20p age \&MaximumPages $=1 \& Z y$ Entry $=3 \#$

Bishop, W. M., T. McNabb, I. Cormican, B. E. Willis, and S. Hyde. 2014. "Operational Evaluation of Phoslock Phosphorus Locking Technology in Laguna Nigel Lake, California.” Water, Air, and Soil Pollution, no. 225: 2018.

Boers, P., J. Van der Does, M. Quaak, J. Van der Vlugt, and P. Walker. 1992. "Fixation of Phosphorus in Lake Sediment Using Iron(III) Chloride: Experiences, Expectations." Hydrobiologia, no. 233: 211-212.

Chowdhury, M. S. A., K. Hasan, and K. Alam. 2014. "The Use of an Aeration System to Prevent Thermal Stratification of Water Bodies: Pond, Lake and Water Supply Reservoir." Applied Ecology and Environmental Sciences 2(1): 1-7.

Coen, L. D. 1995. A Review of the Potential Impacts of Mechanical Harvesting on Subtidal and Intertidal Shellfish Resources. Charleston, SC: Marine Resources Research Institute, South Carolina Department of Natural Resources.

Cooke, G. D., R. T. Heath, R. H. Kennedy, and M. R. McComas. 1978. Effects of Diversion and Alum Application on Two Eutrophic Lakes. EPA-60o/3-78-033. United States Environmental Protection Agency.

Cooke, G. D., E. B. Welch, S. A. Peterson, and P. R. Newroth. 1993. Restoration and Management of Lakes and Reservoirs. Second Edition. Boca Raton, FL.

Cooley, T. N., P. M. Dooris, and D. F. Martin. 1980. "Aeration as a Tool to Improve Water Quality and Reduce the Growth of Hydrilla." Water Research 14: 485-489.

Doudoroff, P. and D.L. Shumway. 1970. Dissolved Oxygen Requirements of Freshwater Fishes. FAO Fisheries Technical Paper No. 86. Food and Agriculture Organization of the United Nations.

Dunne, E. J., and K. R. Reddy. 2005. "Phosphorus Biochemistry of Wetlands in Agricultural Soils." In Nutrient Management in Agricultural Watersheds: A Wetland Solution, edited by E. J. Dunne, K. R. Reddy, and O. T. Carton. Wageningen, The Netherlands: Wageningen Academic Publishers.

Engstrom, D. R., and D. I. Wright. 2002. "Sedimentological Effects of Aeration-Induced Lake Circulation." Lake and Reservoir Management 18(3): 201-214 
Engstrom, D.R. 2005. "Long-term changes in iron and phosphorus sedimentation in Vadnais Lake, Minnesota, resulting from ferric chloride addition and hypolimnetic aeration." Lake and Reservoir Management 21(1):95-105.

Federal Way Mirror. 2014. Twin Lakes Residents Sound Off to Federal Way Mayor over Toxic Algae. Sound Publishing, Inc. http://www.federalwaymirror.com/news/twin-lakesresidents-sound-off-to-federal-way-mayor-over-toxic-algae-photos/.

Fondriest Environmental. 2016. Fundamentals of Environmental Measurements. http://www.fondriest.com/environmental-measurements/parameters/water-quality/ph/.

Gettys, L. A., W. T. Haller, and D. G. Petty, eds. 2014. Biology and Control of Aquatic Plants. A Best Management Practices Handbook. Third Edition. Marietta, GA: Aquatic Ecosystem Restoration Foundation.

Glassner-Shurayder, K. 1993. Keeping It on the Land: Improving Great Lakes Water Quality by Controlling Soil Erosion and Sedimentation. Ann Arbor, MI: Great Lakes Commission.

Grochowska, J., R. Augustyniak, M. Lopata. 2017. "How Durable is the Improvement of Environmental Conditions in Lake after the Termination of Restoration Treatments." Ecological Engineering, no. 104:23-29.

Harris, T. D., V. H. Smith, J. L. Graham, D. B. Van de Waal, L. P. Tedesco, and N. Clercin. 2016. "Combined Effects of Nitrogen to Phosphorus and Nitrate to Ammonia Ratios on Cyanobacterial Metabolite Concentrations in Eutrophic Midwestern USA Reservoirs." Inland Waters 6(2): 199-210.

Herman, B., J. Eberly, C. Jung, and V. F. Medina. 2017. Review and evaluation of reservoir management strategies for Harmful Algal Blooms. ERDC/EL TR-1711. Vicksburg, MS: U.S. Army Engineer Research and Development Center.

Hoverson, D. 2008. Phosphorus Release from Sediments in Shawano Lake, Wisconsin. Masters thesis, College of Natural Resources, University of Wisconsin: Stevens Point, Wisconsin.

Hudson, H., and B. Kirschner. 1997. Lake Notes: Lake Aeration and Circulation. Illinois Environmental Protection Agency and the Northeastern Illinois Planning Commission. http://epa.state.il.us/water/conservation/lake-notes/lake-aeration.pdf.

Hussner, A., I. Steirs, M. Verhofstad, E. S. Bakker, B. M. C. Grutters, J. Jaury, J. L. C. H. van Valkengurg, G. Brundu, J. Newman, J. S. Clayton, L. W. J. Anderson, and D. Hofstra. 2017. "Management and Control Methods of Invasive Alien Freshwater Aquatic Plants: A Review.” Aquatic Botany, no. 136: 112-137.

Indian Lake Improvement Associate. 2016. Status Update for Indian Lake. Presentation for the General Membership Meeting. August 20, 2016. http://indianlakeassociation.org/board/meetingminutes.html.

Jeanneret, D. 1989. Lake Erie Water Quality: Past, Present and Future. OHSU-FS-046. Columbus, OH: Ohio Sea Grant College Program.

Jermalowicz-Jones, J. L. 2012. "Laminar Flow Aeration: A Sustainable Lake Improvement Option." The Michigan Riparian 47(1): 6-8. 
Jermalowicz-Jones, J. L. 2016. Inversion Oxygengation and Bioaugmentation Reduces Invasive Euration Watermilfoil Growth in Four Michigan Inland Lakes. Presentation. Restorative Lake Science. https://www.clean-flo.com/wpcontent/uploads/2016/02/Jones-Milfoil-reduction-on-4-Michigan-lakes.pdf

Jermalowicz-Jones, J. L. 2017. Koontz Lake Ecosystem Assessment and Recommendations for Improvement Starke Count and Marshall County, Indiana. Spring Lake, IN: Restorative Lake Sciences.

JFNew. 2009. Koontz Lake Aquatic Vegetation Management Plan 2008-2012. Marshall and Starke Counties, Indiana. Walkerton, IN.

JFNew. 2010. Koontz Lake Watershed Management Plan. Walkerton, IN.

Kong, X-Z., S. E. Jorgensen, W. He, N. Qin, F-L. Xu. 2013. "Predicting the Restoration Effects by a Structural Dynamic Approach in Lake Chaohu, China.” Ecological Modeling, no. 266:73-85.

Kronvang, B. 2013. "Interactions between Sediment and Water." In Proceedings of the $9^{\text {th }}$ International Symposium on the Interactions between Sediments and Water, 5-10 May 2002 in Banff, Alberta, Canada. Developments in Hydrobiology vol. 169.

Landin, M. C., J. Fowler, and H. H. Allen. 1994. "New Applications and Practices for Beneficial Uses of Dredged Material." In Proceedings of the $2^{\text {nd }}$ International Conference on Dredging and Dredged Material. American Society of Civil Engineering. New York, NY.

Les, D. H., and C. T. Philbrick. 1993. "Studies of Hybridization and Chromosome Number Variation in Aquatic Angiosperms: Evolutionary Implications.” Aquatic Botany 44(2-3): 181-228.

Lewtas, K., M. Paterson, H. D. Venema, and D. Roy. 2015. Manitoba Prairie Lakes: Eutrophication and In-Lake Remediation Treatments. Winnipeg, Manitoba: International Institute for Sustainable Development. No. CONF-750410-P4. New York: John Wiley and Sons, Inc.

Lyon, J., V. F. Medina, and L. Dickinson. 2002. "Treatment of Dairy Wastes Using the InStreem Reactor - A Novel Rotation Reactor.” In Proceedings of the State of Washington Water Research Center Regional Water Quality Conference, Vancouver, WA.

Martins G., L. Peixoto, A. G. Brito, and R. Nogueira. 2014. "Phosphorus-Iron Interaction in Sediments: Can an Electrode Minimize Phosphorus Release from Sediments." Rev Enviro Sci Biotechnol 13(3): 265-275.

McNabb, T. 2011. A New Tool for Proactive Water Quality Restoration. Land and Water. May/June 18-23. http://www.sepro.com/documents/Phoslock/CaseStudies/Phoslock\%20Case\%20Study\%20\%20ANewTool.pdf.

Michigan Department of Environmental Quality (MDEQ). 1994. Dissolved Oxygen. http://www.michigan.gov/documents/deq/wb-npdes-Dissolved0xygen_247232_7.pdf. 
Medina, V. F., R. Fischer, and C. Ruiz. 2016a. Riparian Buffers for Runoff Control and Sensitive Species Habitat on U.S. Army Corps of Engineers Lake and Reservoir Projects. ERDC-WQTN-MS-16-1. Vicksburg, MS: U.S. Army Engineer Research and Development Center.

Medina, V. F., C. S. Griggs, and C. Thomas. 2016b. "Evaluation of the Destruction of the Harmful Cyanobacteria, Microcystis aeruginosa, with a Cavitation and Superoxide Generating Water Treatment Reactor." Bulletin of Environmental Toxicology and Contamination 96(6): 791-796. DOI: 10:1007/S00128-016-1742-6.

Medina, V. F., A. B. Morrow, R. Wade, and C. Thomas. 2016c. Testing of the KRIA Ionizing Water Treatment System for Waters Contaminated with Diesel, PCBs, and Nutrients (Nitrogen Forms). ERDC/EL TR-16-03. Vicksburg, MS: U.S. Army Engineer Research and Development Center. http://acwc.sdp.sirsi.net/client/en_US/search/asset/1048390.

Medina, V. F., S. A. Waisner, S. Cosper, G. Rodriguez, D. Gilbert, R. Tucker, I. MacAllister, R. Scholze, J. Burken, and J. Wang. 2014. Anaerobic Digestion Assessment for Contingency Base Waste. ERDC/EL TR-14-3. Vicksburg, MS: U.S. Army Engineer Research and Development Center. http://acwc.sdp.sirsi.net/client/search/asset/1034690.

Orihel D. M., D. W. Schindler, N. C. Ballard, M. D. Graham, D. W. O'Connel, L. R. Wilson, and R. D. Vinebrooke. 2015. "The 'Nutrient Pump:' Iron-Poor Sediments Fuel Low Nitrogen-to-Phosphorus Ratios and Cyanobacterial Blooms in Polymictic Lakes.” Limnol Oceanogr 6o(3): 856-871.

Palm Beach County Board of County Commissioners. 2015. Pine Lake Phoslock Application. A Chain of Lakes Restoration Project. West Palm Beach, FL. http://discover.pbcgov.org/erm/Publications/PineLakeRestoration.pdf.

Parker, A. K. 2004. The Role of Iron-Rich Sediment in the Biogeochemical Cycling of Phosphorus in Georgia Piedmont Impoundments. Doctoral dissertation, The University of Georgia, Athens, GA.

Pastorok, R. A., M. W. Lorenzen, T. C. Ginn. 1982. Environmental Aspects of Artificial Aeration and Oxygenation of Reservoirs: A Review of Theory, Techniques, and Experiences. Technical Report E-82-3. Washington, DC: U.S. Army Corps of Engineers.

Pearl, H. W., and J. Huisman. 2008. "Blooms Like It Hot.” Science 320:57-58.

Reddy, K. R., R. G. Wetzel, and K. H. Kadlec. 2005. Biochemistry of Phosphorus in Wetlands. American Society of Agronomy, Crop Science Society of America, Soil Science Society of America, 677 S. Segoe Rd., Madison, WI 53711, USA. Phosphorus: Agriculture and the Environment, Agronomy Monograph no. 46.

Schubel, J. R. 1977. "Sediment and the Quality of the Estuarine Environment: Some Observations." In Fate of Pollutants in the Air and Water Environments. Part 1. Mechanism of Interaction between Environments and the Mathematical Modeling and the Physical Fate of Pollutants, edited by I. H. Suffet, 399-424. New York, NY: John Wiley and Sons. 
SePRO. 2014. Water Quality Restoration of a Phosphorus Impaired Lake. http://www.sepro.com/documents/Phoslock/CaseStudies/Phoslock\%20Case\%20Study\%20\%20Pine\%20Lake.pdf.

SePRO 2015. Water Quality Restoration in Laguna Nigel Lake. http://www.sepro.com/documents/Phoslock/CaseStudies/Phoslock\%20Case\%20Study\%20\%20Laguna\%20Niguel.pdf.

Smolders, A. J. P., L. P. M. Lamers, M. Moonen, K. Zwaga, and J. G. M. Roelofs. 2001. "Controlling Phosphate Release from Phosphate-Enriched Sediments by Adding Various Iron Compounds.” Biogeochemistry 54(2): 219-228.

Tacy, P. D., and J. S. Matus. 2001. Koontz Lake, Starke County, Indiana. Report of Findings for Geotechnical Investigation. Detroit, MI: STS Consultants, LTD.

Taranu, Z. E., I. Gregory-Eaves, P. R. Leavitt, L. Bunting, T. Buchaca, J. Catalan, I. Domaizon, P. Guilizzoni, A. Lami, S. McGowan, H. Moorhouse, G. Marabito, F. R. Pick, M. A. Stevenson, P. L. Thompson, and R. D. Vinebrook. 2015. "Acceleration of Cyanobacterial Dominance in North Temperate-Subarctic Lakes during the Anthropocene." Ecology Letters 18(4): 375-384.

Thomaz, S.M., and E. R. da Cunha. 2010. "The Role of Macrophytes in Habitat Structuring in Aquatic Ecosystems: Methods of Measurement, Causes and Consequences on Animal Assemblages' Composition and Biodiversity." Acta Limnologica Brasiliensia 22(2): 218-236.

Toetz, D. W. 1981. "Effects of Whole Lake Mixing on Water Quality and Phytoplankton." Water Research 15(10):1205-1210.

United States Army Corps of Engineers (USACE). 1998. Section 905(b) Expedited Reconnaissance Report for Project Modifications at Koontz Lake, Marshall and Starke Counties, Indiana. Chicago, IL: Great Lakes and Ohio River Division.

Vilá, M., E. Weber, and C.M. D’Antonio. 2000. “Conservation Implications of Invasion by Plant Hybridization.” Biological Invasions 2(3): 207-217.

Vollenweider, R. A. 1975. "Input-Output Models with Special Reference to Phosphorus Loading Concept in Limnology.” Scheiz. Z. Hydrology 37(1): 53-84.

Weiss, C. M., and B. W. Breedlove. 1973. Water Quality Changes in an Impoundment as a Consequence of Artificial Destratification. PB-219 390. Report no. 80. Water Resources Research Institute of the University of North Carolina.

Welch, E. B., and G. D. Cooke. 1999. "Effectiveness and Longevity of Phosphorus Inactivation with Alum." J. Lake and Reserv. Manag. 15(1): 5-27.

Whitin, S., and T. Twohig. 2007. "Restoration of Mussachuck Creek and Rhode Island Country Club - A Federal and Private Partnership. Restoring Our Natural Habitat." In Proceedings of the 2007 World Environmental and Water Resources Congress. American Society of Civil Engineers, Reston, VA.

Wisconsin Department of Natural Resources (WDNR). 2003. Alum Treatments to Control Phosphorus in Lakes. http://www.littlesaint.org/misc_documents/alum_phosphorous_control_dnr.pdf. 
Wurts, W. A. 2003. "Daily pH Cycle and Ammonia Toxicity." World Aquaculture 34(2): 20-21.

Yu, J., C. Fan, J. Zhong, Y. Zhang, C. Wang, and L. Zhang. 2016. "Evaluation of In Situ Simulated Dredging to Reduce Internal Nitrogen Flux across the Sediment-Water Interface in Lake Taihu, China." Environmental Pollution, no. 214: 866-877. 


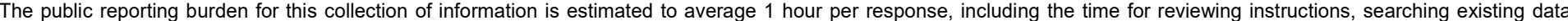

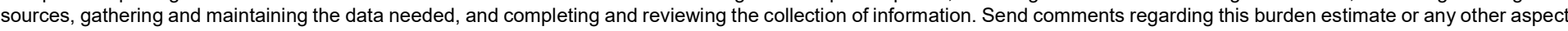

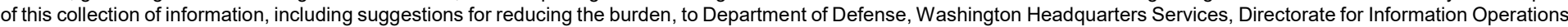

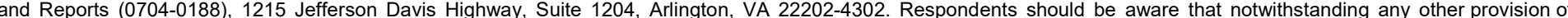
law, no person shall be subject to any penalty for failing to comply with a collection of information if it does not display a currently valid OMB control number.

PLEASE DO NOT RETURN YOUR FORM TO THE ABOVE ADDRESS.

\section{REPORT DATE}

January 2018

\section{TITLE AND SUBTITLE}

Evaluation of Koontz Lake (North Indiana) Ecological Restoration Options - Comparison of Dredging and Aeration - and Broad Application to USACE Projects

\section{DATES COVERED (From - To)}

5a. CONTRACT NUMBER

5b. GRANT NUMBER

5c. PROGRAM ELEMENT NUMBER

5d. PROJECT NUMBER

TA2017-002

5e. TASK NUMBER

5f. WORK UNIT NUMBER

8. PERFORMING ORGANIZATION REPORT NUMBER

ERDC/EL TR-18-2

U.S. Army Engineer Research and Development Center

3909 Halls Ferry Road

Vicksburg, MS 39180-6199

\section{SPONSORING/MONITORING AGENCY NAME(S) AND ADDRESS(ES}

Water Operations Technical Support

3909 Halls Ferry Road, Vicksburg, MS 39180

\section{SPONSOR/MONITOR'S ACRONYM(S) \\ WOTS}

\section{SPONSOR/MONITOR'S} REPORT NUMBER(S)

\section{DISTRIBUTION/AVAILABILITY STATEMENT}

Approved for public release; distribution is unlimited.

\section{SUPPLEMENTARY NOTES}

\section{ABSTRACT}

Koontz Lake is located in Northern Indiana. The lake has had problems with eutrophication, harmful algae, invasive plants, and shallowing due to accumulation of sediment and muck. A study was conducted to assist in evaluating between two ecological restorative options under consideration: aeration and dredging. In this report, both approaches are defined, and various options of each are discussed. The impact of each approach is assessed for key water quality/ecological parameters. The specific needs of Koontz Lake are then discussed. In the case of Koontz Lake, the shallow portions of the lake appear to limit the effectiveness of aeration. Dredging would allow increased recreational use of the lake, particularly minimizing limitations on boating speeds. However, aeration could be integrated for long-term management of the lake. This report summarizes recommendations for Koontz Lake that have a greater applicability to other U.S. Army Corps of Engineers lake/reservoir projects. Several other alternatives are also presented, specifically the use of PhosLock, iron, and alum to bind phosphorus in sediments. (The U.S. Army Engineer Research and Development Center does not endorse any specific products or brands).

\section{SUBJECT TERMS}

Dredging, Environmental management, Environmental protection, Eutrophication, Koontz Lake (Ind.), Lakes-Aeration, Sedimentation and deposition, Water quality

\section{SECURITY CLASSIFICATION OF:}

\begin{tabular}{|l|l|l|}
\hline a. REPORT & b. ABSTRACT & c. THIS PAGE \\
Unclassified & Unclassified & Unclassified \\
\hline
\end{tabular}

17. LIMITATION OF ABSTRACT

SAR
18. NUMBER OF PAGES

51 19a. NAME OF RESPONSIBLE PERSON

Victor F. Medina

19b. TELEPHONE NUMBER (Include area code) 601-634-4283 